Florida International University FIU Digital Commons

$11-2-2017$

\title{
An Unreceptive Audience: The Mixed Receptions of Mark Twain's and J.D.Salinger's Novels in the 1950s and 1960s
}

Marlene Tovar

mtovar@fiu.edu

DOI: $10.25148 /$ etd.FIDC004021

Follow this and additional works at: https://digitalcommons.fiu.edu/etd

Part of the Arts and Humanities Commons

\section{Recommended Citation}

Tovar, Marlene, "An Unreceptive Audience: The Mixed Receptions of Mark Twain's and J.D.Salinger's Novels in the 1950s and 1960s" (2017). FIU Electronic Theses and Dissertations. 3545.

https://digitalcommons.fiu.edu/etd/3545

This work is brought to you for free and open access by the University Graduate School at FIU Digital Commons. It has been accepted for inclusion in FIU Electronic Theses and Dissertations by an authorized administrator of FIU Digital Commons. For more information, please contact dcc@fiu.edu. 


\title{
FLORIDA INTERNATIONAL UNIVERSITY \\ Miami, Florida
}

\section{AN UNRECEPTIVE AUDIENCE: THE MIXED RECEPTIONS OF MARK TWAIN'S AND J.D. SALINGER'S NOVELS IN THE 1950S AND 1960S}

\author{
A thesis submitted in partial fulfillment of the \\ requirements for the degree of \\ MASTER OF ARTS \\ in \\ ENGLISH \\ by
}

Marlene Tovar 
To: Michael R. Heithaus

College of Arts, Sciences, and Education

This thesis, written by Marlene Tovar, and entitled An Unreceptive Audience: The Mixed Receptions of Mark Twain's and J.D. Salinger's Novels in the 1950s and 1960s, having been approved in respect to style and intellectual content, is referred to you for judgment.

We have read this thesis and recommend that it be approved.

Martha Schoolman

Michael Patrick Gillespie

Nathaniel Cadle, Major Professor

Date of Defense: November 2, 2017

The thesis of Marlene Tovar is approved.

Dean Michael R. Heithaus

College of Arts, Sciences and Education

Andrés G. Gil

Vice President for Research and Economic Development

and Dean of the University Graduate School

Florida International University, 2017 


\section{ABSTRACT OF THE THESIS}

\section{AN UNRECEPTIVE AUDIENCE: THE MIXED RECEPTIONS OF MARK TWAIN'S}

AND J.D. SALINGER'S NOVELS IN THE 1950s AND 1960s

by

Marlene Tovar

Florida International University, 2017

Miami, Florida

Professor Nathaniel Cadle, Major Professor

This thesis examines how the sociopolitical contexts of the mid-twentieth century influenced readers' interpretations of Mark Twain's novel “The Adventures of Huckleberry Finn” and J.D. Salinger's “The Catcher in the Rye," two controversial novels that were subjected to censorship activity. In particular, this thesis will focus on the reception of both of these novels during the 1950s and 1960s, a period marked by two major events: The Civil Rights Movement and the youth counterculture phenomenon. In this study, the reception of "Huckleberry Finn" will be analyzed in the context of the civil rights movement, using news articles published in the 1950s and 1960s to illustrate how the different interpretations of readers prompted school board directors to ban the book from junior high and high school reading lists. 


\section{TABLE OF CONTENTS}

CHAPTER

PAGE

Introduction: Twain's and Salinger's Polarized Readerships 1

Chapter 1: Reception of "Huckleberry Finn": A "Classic" to White Liberals but a Burden to Minority Readers.......................................................................................... 11

Chapter 2: Reception of "Catcher in the Rye": A Relatable Novel for Teenage Readers, but a Threat to Traditional Conservatives.............................................................................38

Coda: Polarized Readerships and Strategies to Defuse Controversies ..........................60

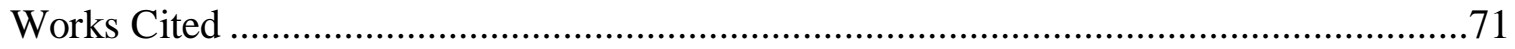


Introduction: Twain's and Salinger's Polarized Readerships

This thesis examines the reception of Mark Twain's The Adventures of Huckleberry Finn and J.D. Salinger's The Catcher in the Rye, published in 1884 and 1951, respectively, two canonical works of literature whose status as required reading in high schools has been frequently questioned and challenged. However, my study specifically focuses on the controversies that occurred during the 1950s and 1960s. These two decades are marked by significant social changes in the United States that were shaped by the civil rights movement and the youth counterculture phenomenon. In my study, the civil rights movement serves as my point of reference to examine the controversies surrounding Twain's novel, while the youth counterculture movement contextualizes Salinger's. I will show the effects these two novels had on these major social movements, and illustrate why opponents of these novels wanted to ban them, and finally, in a brief coda, propose strategies to defuse possible controversies in the longterm regarding other novels using Alison Bechdel's Fun Home as an example.

Readers who disapproved of Twain's and Salinger's novels initiated protests to have them removed from junior high and high school reading lists. When readers protested against these novels, superintendents and school board committee members responded by asserting their reliance on teachers' judgment and expertise. Relying on teachers' expertise appeared to defuse the situation surrounding the Catcher controversies, thereby proving to be an effective strategy in resolving the conflict; however, it proved to be ineffective in handling Huckleberry Finn. By relying on 
teachers' expertise when addressing the controversies of Twain's novel, superintendents and school board members were silencing minorities of color, who had valid reasons for being concerned. The use of the " $n$ " word in the novel was indeed problematic because it was conveying to readers that its usage was acceptable. Thus, my study has lead me to conclude that while it is necessary to rely on teachers' expertise, it is also imperative for authorities to include minority readers, especially those who feel threatened or excluded by the novels they protest, in this dialogue before deciding to ban novels.

My study takes a sociological approach to literary history, using Twain's and Salinger's novels as primary sources and newspaper articles produced between the years of 1950-1970 as secondary sources. Additionally, I apply reception theory to examine how readers responded to Twain's and Salinger's novels. I use reception theory akin to the way historians use it, which scholars Philip Goldstein and James L. Machor describe as an emphasis on "the sociohistorical contexts of reading practices" (Goldstein and Machor xix). By using reception theory, I examine the different ways that readers interpreted Twain's and Salinger's novels. My objective in using these methods is to observe how writers were depicting readers' responses in news media, as well as how they were depicting the controversies surrounding these novels. In my analysis of the primary texts, I reconstruct the interpretations of opponents of these novels, and I supply my own interpretation of key passages that help to explain the controversies surrounding the novels. In examining the news articles, I analyze the possible reasons why protesters felt threatened about having these books on high school reading lists. I also look at the responses from more receptive readers, and examine how they interpreted these novels 
differently from protesters. Consequently, I observe how these receptive readers use their interpretations to argue in support of including these novels on junior high and high school reading lists.

When examining how opponents interpreted the subject matter and, most importantly, the narrative mode of these novels, I identify specific passages that may have appalled or offended these readers. The narrative mode is an essential aspect of both novels, because both Twain and Salinger made the artistic choice of featuring two vernacular speaking protagonists. Receptive readers came to identify with Twain's protagonist Huckleberry Finn and Salinger's Holden Caulfield, holding these two characters in high esteem. It was Huck's morals and Holden's sense of isolation, conveyed through their vernacular speech, that readers found insightful and relatable. However, it was also the vernacular speech used by Twain's and Salinger's protagonists that protesters invoked as the chief reason for wanting these books banned.

Twain and Salinger had polarized readerships, with segments of readers praising their use of first-person point of view and others lambasting it. For example, as I show in the first chapter, Twain's primary readers during the civil rights movement were white bourgeois liberals, and the ones who objected to it were mostly people of color. White liberal readers identified themselves with Twain's protagonist Huck, interpreting him as a virtuous character because of his friendship with Jim. By identifying with him, white liberals were insinuating that they were also virtuous and in support of racial desegregation. Examining reports in newspaper articles and key passages from the novel enabled me to become aware of how white liberals appropriated Twain's novel, using it 
for self-praise and as evidence that they supported the cause of the civil rights movement.

By contrast, readers who objected to these novels expressed their concern over Huck's and Holden's use of profanity. Readers who challenged Twain's novel criticized the incessant use of the " $n$ " word by the white characters and protagonist. Opponents of Salinger's book cited his blasphemous language as offensive, though in my second chapter I will discuss how Holden's obscene language was used as a pretext by parents who were not fully able to articulate their underlying reasons for wanting the novel banned. Salinger's primary readers were teenagers, who, like the white liberals reading Twain, identified with Holden. Unlike Twain's readers, though, they identified with Holden's sense of isolation and uncertainty. Holden's authenticity resonated with teenage readers, and he provided them with insights about their own identities and sense of belonging.

In my first chapter, I focus on the reception of Huckleberry Finn. I examine how the novel was received in the 1950s and 1960s, during the civil rights movement, noting how literary critics and cultural authorities were relied upon to dismiss the interpretations of minority readers. In this chapter, I demonstrate that the use of the "n" word and Twain's depiction of Jim thwarted the efforts of civil rights leaders for equality and also reinforced their oppressed positions. These concerns of minority readers were disregarded by writers and journalists, who often sided with the interpretations of experts. In fact, journalists often chose to emphasize the interpretations of experts in their reports and portray minorities as ignorant readers, frequently claiming 
that Huckleberry Finn protesters simply "did not know how to read a good book" (Fairchild). Most writers and journalists were insensitive towards minority readers and tended to trivialize their legitimate concerns.

Throughout my first chapter, I also consider how Twain's use of dialect as a literary technique was problematic. Specifically, I examine how his use of dialect for Jim, as well as Twain's reliance on minstrel conventions to portray him, offended minority readers. Minority readers argued that Twain's rendition of Jim as ignorant and gullible was misrepresentative of their race. During one protest initiated by black high school students in 1964, one protester claimed that Twain's depiction of Jim was conveying to white high school students that their entire race was illiterate and uncultivated. At such a pivotal historical moment, Twain's novel was perpetuating negative racial stereotypes, which undermined the efforts by black civil rights leaders for equality. I also examine how what I am calling receptive readers countered these objections, invoking the interpretations made by literary critics such as Lionel Trilling about how Twain was simply depicting history accurately.

For my second chapter, I look at how readers interpreted The Catcher in the Rye, using the youth counterculture movement as a backdrop. Similar to my approach to Huckleberry Finn, I examine the interpretations of both receptive readers and opponents of the novel. The receptive readers were mainly teenagers, who were reported to have expressed indignation at the school board's decision to ban the book without including them in the conversation. Opponents of the novel were mostly parents, though there were a few cases where school board members disapproved of having the novel taught 
in classrooms. These opponents of Salinger's novel usually cited the obscene language as a reason for censorship activity. Other dissenters questioned Salinger's book as a work of literature, with one parent claiming that Salinger's book lacked the characteristics that other "good" works of literature have. Contrasting the responses from readers who objected to Salinger to those who advocated for the inclusion of his novel reveals how unjust it was for parents and unreceptive readers to deem a literary work as "lacking in merit" when, clearly, it was meaningful to teenage readers.

While Salinger also uses dialect, just as Twain did, literary scholar Pamela Steinle asserts that language was only an ostensible reason for banning Salinger's novel. In her book In Cold Fear: 'The Catcher in the Rye' Censorship Controversies and Postwar American Character, Steinle assesses the controversies across communities in the country and illustrates that parents felt that Salinger's novel would persuade their children to reject their traditional American values. Building on Steinle's work, my second chapter also discusses how Salinger's novel posed a threat to parents' American identities and their traditional values. I examine parents' criticism of the novel and illustrate how their comments subtly reflected their fears of having their values subverted. Holden's social critique of American values is what offended them, as well as his assertion that adults are deceitful. Teenage readers, on the other hand, appreciated Holden's insights and identified with his fear of growing up. Two high school honors students explained their concern over having the novel banned in an article titled "Literary Controversy" published in the The Los Angeles in 1964. In contrast to opponents, they viewed Salinger's novel as an "educational classic”. Thus, my study led 
me to empathize with both Twain's and Salinger's minority readers, who may have had different objectives but whose voices were excluded from the conversations regarding censorship.

Finally, in my coda, I offer strategies derived from these two case studies that can be used to manage current and potential future controversies and censorship activity. These strategies can serve to mollify protests and anxieties over racy content and obscene language in novels. As an example, I examine the recent controversies surrounding Alison Bechdel's memoir Fun Home, published in 2006. I review how conservative Christian students at Duke University in North Carolina responded to Bechdel's memoir, and, considering how superintendents and school board members handled the controversies of Twain's and Salinger's novels, conjecture possible strategies that could be implemented to defuse such controversies. The strategies I propose are to rely on the expertise of teachers, create a forum for protesters, and to include students and minority readers in the dialogue of such controversy and censorship activity. Teachers should be viewed as credible and authoritative sources in designing and selecting course material. Furthermore, I discuss why it is vital for superintendents, school board members, and parents to allow teachers the autonomy to select readings. However, the voices of parents, as well as of students, also need to be heard. The second strategy I consider equally vital, which is to provide protesters a venue in which they can explain their disapproval of novels. Whether protesters are the majority or contrarians, it is necessary for school boards and faculty to allow them to express their objections to novels and compromise over solutions that will benefit both sides. Lastly, it is necessary 
for the voices of minority readers to be included in the dialogue with the cultural authorities and experts. In the case of Catcher, the voices of teenage readers were important given that they were the ones studying the material. Just as teachers should teach books they find educational, students should also be studying books they find instructive.

Teachers should indeed be entrusted to select readings they find educational for their students; however, they simultaneously need to adopt pedagogical practices that are adequate for a diverse classroom. Twain's and Salinger's novels are literary works that tackle significant themes and that, because of their innovative narrative mode, can be interpreted in rich, multiple ways. Despite their expertise, teachers should not have promoted a single, "correct" interpretation of Huckleberry Finn. English teachers need to be wary when they teach literary texts that address serious issues of race, class, and identity. They should implement pedagogical practices that are inclusive of minorities and that demonstrate cultural sensitivity. In teaching a literary text, English teachers should be mindful of how students' diverse cultural backgrounds inform their interpretations. Moreover, literary critic Rita Felski's main argument in her book The Limits of Critique has also informed my view of how teachers should respond to students' and protesters' affective readings of literary texts. In The Limits of Critique, Felski argues that critics should engage in postcritical readings of texts, which she describes as being the opposite of prescribing "the forms that [a] reading should take" (Felski 173). She explains that French critics are applying a postcritical approach to literary texts, a new method of critique, in which they are "[b]lending phenomenology 
and pragmatics, Foucalt and Fish [and]these critics offer a fresh take on questions of reading: one that embraces its affective as well as cognitive aspects" (Felski 175). English teachers should also embrace affective readings in their classrooms and consider how it can complement traditional literary instruction. My examination of how Twain's and Salinger's novels were received in the 1950s and 1960s, as well as of Felski's argument, have led me to conclude that affective readings of texts are just as valid as traditional literary critique. Literary critique is what the teachers and literary critics offered and used to disregard the interpretations of minority readers in the case of Twain's novel. Teachers should offer their interpretations and explain how theoretical frameworks informed them, but they also need to be responsive to different interpretations from their students and parents.

Removing these two canonical works from reading lists without a forum in which minority readers, parents, and the experts could engage in dialogue was detrimental. The objections of Huckleberry Finn opponents should have been taken into account. If school board members and teachers would have agreed to listen to them, perhaps they could have negotiated effective techniques of teaching the novel in classrooms with minority readers. Teachers could have gained minority readers' input on how to address the harmful effects of Twain's stereotypical depiction of Jim. In the case of Catcher, it was just as problematic for school board members to ban a novel that interested teenage students and that they considered an "educational classic." Because teachers, parents, students, and minority readers are affected when superintendents or 
the school board decides to ban a novel, they need to be included in the decision-making process. 
Chapter 1: Reception of Huckleberry Finn: A "Classic” Novel to White Liberals but a Burden to Minority Readers

The novel that literary critic Shelley Fisher Fishkin claims "transformed American literature" by employing point-of-view in an innovative fashion is also known to be controversial for its incessant usage of the " $n$ " word and its patronizing depiction of the slave Jim. Mark Twain's Huckleberry Finn, published in 1884, elicited protests from readers in the 1950s and 1960s who were offended by what they deemed racist language in the novel. These readers attempted to have the novel banned from junior high and high school reading lists for various reasons. Literary critics who have studied Twain's novel, like Fishkin, have demonstrated that Twain's use of dialect and vernacular was inspired by rich oral traditions, including African-American ones. In this chapter, I will examine and link these two interpretations of the novel. I will conduct a case study of the reception of Huckleberry Finn in the 1950s and 1960s, focusing on Twain's usage of dialect as the crux of interpretive disagreements among readers. With my case study, I will show how Twain's use of dialect became problematic at a time when black civil rights activists, such as Martin Luther King Jr, were gaining national recognition for their eloquence. I argue that Twain's use of the "n" word ${ }^{1}$ and his stereotypical depiction of Jim were perceived as a threat to minority readers because these forms of representation had the potential to thwart their advancements for equal rights and reinforced those readers’ oppressed positions.

\footnotetext{
${ }^{1}$ Because it is a crude term that was used to reinforce the oppressed positions of the black race and that, even in the present day, still has the power to demean and objectify them, I have made the conscious decision of refraining from spelling out the " $n$ " word in this thesis.
} 
In the mid 1950s, as Jim Crow laws were beginning to be challenged in systematic ways, minorities found that racist policies were changing without support from white bourgeois liberals. In fact, Twain's novel served as a defense mechanism for white liberals, who appropriated his novel to claim that, like Twain's protagonist, they were empathetic towards African Americans. They claimed that they endorsed and were open-minded toward racial integration. Interpreting Twain's novel as conveying an antiracist message, white liberals identified themselves with Huck, who to them embodied good morals and a noble attitude towards people of color. Three professors who studied Huckleberry Finn in the late 1940s informed the interpretations of white liberals and their appropriation of the novel in the 1950s and 1960s. Lionel Trilling, Walter Blair, and Henry Nash Smith were responsible for generating its hypercanonization. According to scholar Jonathan Arac, hypercanonization involved teaching students to close read the novel, focusing on specific passages that divulged its main themes. Hypercanonization eventually led to idolization of the novel because it was viewed as a "quintessential" representation of American values. In Huckleberry Finn, there were two key passages that Arac cites as, "hypercanonized parts within the hypercanonized whole" (6). One is from the first page of chapter 19, which critics highlighted because of Huck's display of American "vernacular" language (Arac 7). The second passage comes from chapter 31, when Huck is about to write the letter to Miss Watson to tell her where she can find her former slave Jim but refuses to do so. It is this scene that cultural authorities read as exemplifying the literary device of irony and that white liberals later invoked as evidence of their own selfless nature. Although minority readers argued that the novel was offensive and referred to several passages as evidence, white liberals and cultural 
authorities held on to their convictions about the novel. To them, Twain recounted the story of a kindhearted boy who made a moral decision by choosing to help Jim escape slavery. White liberals were not directly thwarting the efforts of civil rights leaders and minorities, but their appropriation of the novel demonstrates that they used Huckleberry Finn to bolster their own self-importance.

An incident that occurred in a public school in Little Rock at the start of the school year in 1957, when it was expected to begin adjusting to desegregation, served to consolidate the hypercanonized views of a white educator. On September 4 1957, when nine black students were turned away from Central High School by national guardsmen, a professor of English from Manhattan wrote a letter to the New York Times referring to the incident. The professor was Hoxie N. Fairchild from Hunter College, who disapproved of the board of education's decision to remove the novel from elementary and junior high reading lists because of parents' protests. In his letter, Fairchild states, “[Huckleberry Finn] is a great document in the progress of human tolerance and understanding. Huck begins by regarding Jim, the fugitive slave, very much as the juvenile delinquents of Little Rock regard the Negro today" (Fairchild). Fairchild is arguing that Twain's novel teaches readers how to be compassionate towards others despite their race. He even compares Huck's earlier attitude towards Jim with that of the students in Little Rock, characterizing him as an intolerant young white boy who eventually learned to be compassionate through the time he spent with Jim. His comparison, however, is inadequate because Huck never displays intolerance or discrimination against Jim in the novel. Although there are a few scenes where Huck feigns bigotry towards slaves, he 
never discriminates against Jim deliberately. Twain employs first-person narration to give readers access to Huck's thoughts, and illustrates that Huck believes feigning bigotry will enable him to continue helping Jim escape. Fairchild, however, has created an analogy where he is implying that southern whites are as intolerant towards blacks as Huck was at the beginning of the novel. Moreover, he may not explicitly state it, but Fairchild suggests that northern whites embody Huck's empathy in the latter part of the novel because they have accepted integration policies. The incident in Little Rock indeed solidified his interpretation of the novel, which northern whites also shared.

Northern whites in New York may have accepted integration, but Fairchild, and other white readers, began oppressing northern African Americans by silencing them. In his letter, Fairchild rebutted the accusations of Twain's novel being offensive. In fact, he defends the novel zealously and denounces parents for objecting to it. He affirms that, "[a]t all events, one thing is certain: whatever his skin pigmentation, any adult who objects to this enlightened work because Huck calls Jim a 'nigger' rather than a 'Negro' simply does not know how to read a great book. It is the duty of the board of education to resist, not to encourage, pressures exerted by such persons" (Fairchild). As my study will show, Fairchild's reaction to the protests by African American parents was a commonplace response by critics and others in the media industry. Although he is decrying all adults who object to the novel despite their "skin pigmentation," Fairchild's remarks are far from subtle. Fairchild's statement, which he cunningly framed to make it appear all-inclusive, was specifically aimed at African Americans. In his discussion of this Times article, Arac observes that by protesting and succeeding in getting the book 
removed, African Americans were perceived as being bigots (65). Their bigotry was compared to the whites in Arkansas who resisted integration. Fairchild's claim that they do not know how to "read a great book" was a false equivalence, and his claim that African-American readers do not know how to read Huckleberry Finn suggests that there is only one way to experience the novel. Furthermore, it is Fairchild who is prejudiced, not minority readers. Although some periodicals, such as The Christian Science Monitor did publish letters by readers who opposed teaching the novel, it was the voices of white liberal readers that appeared in the articles and dominated the discussions regarding the novel. Thus, the voices that prevailed in this debate were those of white liberals who agree with Fairchild, and whose rhetoric implies that minority readers are being too simpleminded to understand Twain's novel.

While disagreements between white and minority readers continued for decades after the book first appeared, 1957 was a key year of the controversies, because some states were desegregating as Huckleberry Finn was removed from reading lists. In the article "School Ouster of Huckleberry Finn Draws Fire" published in the Chicago Daily Tribune on September 13, 1957, the anonymous writer notes how African American readers felt offended by the pejorative language in the novel. The book was reportedly dropped from reading lists "because some negroes criticized the book as offensive to their race" ("School Ouster of Huckleberry Finn Draws Fire"). The writer explains that the book was banned from school reading lists but was still distributed in school libraries. In the article, the author underscores that "Mark Twain's book 'The Adventures of Huckleberry Finn' which was dropped from New York City's textbook lists, reportedly 
'because of passages derogatory to Negroes' is not used as a textbook, in Chicago public schools" (School Ouster of Huckleberry Finn Draws Fire). The book's loss of status as a "textbook" because of the criticisms it received from black readers illustrates how these readers' affective reception of the novel determined whether Twain's book held any educational merit in that particular district. More importantly, it underscores the impact the novel continued to have on minority readers in such a pivotal moment in history, where these "passages derogatory to Negroes" categorized the black race as being illiterate and ignorant.

In another article that appeared in The Christian Science Monitor titled "This the Negro Owes Himself," the writer's attitude toward the criticisms by black readers over Jim's portrayal is dismissive. In fact, the author praises Twain's depiction of Jim, suggesting that Twain accurately captured the linguistic attributes of slaves in the 1840s, where the novel is set. The writer asks if readers are offended "[b]ecause Jim is made to say things like, 'I see a light a-coming round de p'int bymeby?' How would a Negro farmhand of Pike County, Missouri have spoken in those days?" ("This the Negro Owes Himself"). By posing these questions, the writer is arguing that Twain was merely representing the typical slave of the 1840s, thus refuting that Jim's depiction is offensive. Considering the novel's removal from the readings lists of elementary and high schools in New York City, the writer mockingly asks, "Why? Because some Negroes have called it 'racially offensive'. And why again? Because the book's perhaps outstanding character 'Nigger Jim' was a slave? What else could he have been in the south of the 1840s?" ("This the Negro Owes Himself"). The writer's assumption that Jim could not have been 
more than a slave in the 1840 s is itself denigrating. Around the 1840 s, there were many erudite black writers who were gaining recognition for their intellect and discourse against slavery. An example is Frederick Douglass, who wrote and published two autobiographies recounting his experience in bondage and was admired for delivering powerful orations against slavery. Frederick Douglass was a prominent figure among abolitionists, and his intellectual abilities illustrate that not all African Americans in the 1840s were gullible and illiterate. Thus, the writer of The Christian Science Monitor may be praising Jim, but he is incorrectly implying that Africans were incapable of being anything more than illiterate slaves. He is demonstrating his own ignorance on the history of slavery and unfairly neglecting the concerns of minority readers. By refusing to understand their perspective, the writer appears to be unconcerned about how the "racially offensive language" was inimical to their cause for equal rights. Thus, minority readers were challenged by readers in authoritative positions who chose to trivialize their concerns over the novel and took Twain's depiction of Jim's gullibility and ignorance as the paragon of people of color in the 1840s.

Twain used the literary technique of dialect to endow his characters with realistic speech patterns, but in rendering Jim Twain relied too heavily on eye dialect. The critic from the article discussed above suggests that Jim speaks exactly as slaves did in the 1840s, without considering how it undermined the intellect and work of civil rights activists. In the passage that the critic refers to, Jim is explaining to Huck why he has run away. Jim tells Huck, “I see a light a-comin' roun' de p'int bymeby, so I wade' in en shove' a'log ahead o'me, en swum agin de current tell de raff come along”' (Twain 43). 
What the misspelled words emphasized to readers was Jim's ignorance rather than his actual speech sounds. Eye dialect conveyed Jim's illiteracy, and therefore elicited protests and criticism from black readers. Having been deemed as a "masterpiece of literature and as the highest image of America" (Arac 6) by scholars and critics, the novel received negative responses from readers out of fear that African Americans would not be able to transcend the stereotypical image of the ignorant black man with such a prominent character representing their race. Moreover, Twain's representation of Jim stood in stark contrast to the articulate black civil rights activists leading the movement. Jim's nonstandard English is almost unintelligible compared to the dialect of Huck and the other white characters, for which Twain did not rely as much on eye dialect.

Huck's vernacular speech can be difficult to decipher in some passages, but his speech is more intelligible than Jim's. In his analysis of the dialects in Huckleberry Finn, David Carkeet observes the main differences between Huck's and Jim's speech patterns. According to Carkeet, Jim displays a wide loss of the consonant $r$, substitutes the voiceless th sound with $f$ (he says mouf instead of mouth) and voices th with $d$ (such as dese instead of these) among other linguistic attributes (317). He notes that Huck does not display any of these features, which Twain gave to Jim to distinguish his "Negro dialect" from the other dialects in the novel. Because Twain made less complicated choices with Huck's dialect, his speech is easier to understand than Jim's. For example, in chapter ten, Huck relates how "[a]fter breakfast I wanted to talk about the dead man and guess out how he come to be killed but Jim didn't want to...I didn't say no more, but I couldn't keep from studying over it and wishing I knowed who shot the man” (50). 
Although Huck's speech is grammatically incorrect and he is using wrong verb inflections, it is not difficult to discern what he is communicating here. His colloquial language is straightforward and his interest in learning more about the dead man and who killed him is clear. In this same scene, Huck even demonstrates strong vocabulary in his speech when he later says, "We rummaged the clothes we'd got" (Twain 50). In general, Huck is a credible character, but his use of the word rummage in this passage diminishes his credibility. Given that the character profile Twain created for Huck is that of a poor and uneducated fourteen-year old boy, his use of such a sophisticated word seems out of character. Moreover, Huck's speech only violates grammar and verb tense rules, while a chief characteristic of Jim's speech is his nonstandard spelling.

In contrast to Huck, Jim displays much more eye dialect, which deemphasizes Huck's illiteracy. Twain's depiction of Huck underscores his low social status and his lack of education and literacy in the novel; yet Twain wrote Huck's dialogue with barely any nonstandard spellings of words. Writing Jim's dialogue with excessive misspelled words conveys the impression that he could not read nor write. Carkeet observes that while both Huck's and Jim's dialect is grammatically the same, in areas where they do share nonstandard rules Jim's frequency is higher than Huck's (Carkeet 317). He also states that Twain used more eye dialect for Jim's prose than Huck's, which undercuts Twain's efforts to use dialect as a literary technique to portray his characters authentically. Because he did not use eye dialect as much to write Huck's prose, ordinary readers who identified with Jim were offended by Twain's emphasis on Jim's illiteracy. 
Nonetheless, critics continued to justify Twain's depiction of Jim in newspaper articles. Some critics were even arguing that Twain's rendition of Jim and of the antebellum culture were unimpeachably realistic representations of history. In fact, many writers justified the offensive language by claiming that history was being represented with "accuracy," a point that will be examined further in this chapter. In another article appearing in The Wall Street Journal, the journalist also makes the same argument as the critic from "The Negro Owes Himself." She argues that the book "ranks pretty high among American classics because it is an accurate portrayal of the history of the times...[T]o want to destroy Jim because Twain portrayed faithfully the customs and dialect of the age and place Jim lived in strikes us as pretty senseless for any minority to want to destroy a book that's actually a powerful tract for human dignity" (Huckleberry Finn). The journalist's assertion suggests that the book gained its status as a "classic" from readers who were in the majority, such as cultural authorities and literary critics. Her tone towards minorities who oppose the novel is imperious as she imposes her reading of the novel as a "powerful tract for human dignity." Rather than attempting to understand why minority readers were offended by Jim's dialect, the writer first assumes and then disregards their concerns. She instead chastises them and accuses them of trying to expunge Jim from the historical record. Furthermore, her claim that Twain portrayed history accurately is problematic, and cannot serve to justify the offensive language.

After asserting that Twain was replicating history "accurately," the journalist proceeds to downplay the acuteness of the crude language. She distinguishes between how the "n" word was used carelessly in the past in contrast to the present, suggesting 
that it is not used at all in the present. The journalist claims that Huckleberry Finn is "the story of a youngster's life along the Mississippi in the 1840s, when things were quite different from nowadays. For one thing, there was slavery in those days and for another people weren't as careful about their speech as they are now" (Huckleberry Finn). Of course, the journalist is referring to the coarse language in the novel and the " $n$ " word in particular. What the journalist is insinuating is that people are aware of the pejorative connotations held by the "n" word and have developed racial sensitivity. However, she is also suggesting that, because the story takes place in a different time period, when the " $n$ " word was used habitually, its use in the novel does not have any effect in the present. Instead, by contrasting her modern society to the antebellum period, the journalist is focusing on the progress already made. She is emphasizing how people in her modern world have higher morals because they are more "careful" with their language. By denying that the novel's language continues to have any effect in her modern society, she is neglecting the progress that still needed to be made and that black civil rights leaders were actively working towards. What the writer's argument in defense of Huckleberry Finn divulges is that literary critics and other cultural authorities at the helm of interpretive communities were defining what constituted as an "accurate" portrayal of history, and imposing a single reading of the novel. Regardless of which characters used the " $n$ " word or how they used it, however, its frequent use elicited indignation from minority readers, a point that this writer consistently downplays.

While there are no passages where Huck openly expresses contempt for people of color, his excessive use of the "n" word was still offensive to readers. In the first chapter, 
Huck uses the "n" word casually as he tells readers how before going to bed "they fetched the niggers in and had prayers" (Twain 7). When Jim is introduced in chapter two, Huck again uses the " $n$ " word to relate how many people came to listen to Jim's stories. He states that "Niggers would come miles to hear Jim tell about it, and he was more looked up to than any nigger in that country" (9). Both of these passages, where the "n" word appears to be used innocuously by Huck, illustrate that he was accustomed to using it. Huck is also a fourteen-year old boy who utters, repeats, and relies on the language in his environment to communicate. However, as an explanation this still cannot justify its negative connotations or how the word emotionally affected minority readers. Given the friendship Huck develops with Jim and his actions throughout the novel, it is indisputable that Twain created a bildungsroman where a young boy demonstrates that his morals differ from the adult characters. Huck's excessive use of the "n" word, however, problematizes this aspect of the novel, and was problematic because it gave the impression to readers that using the word remains acceptable, even after Huck defines himself morally, especially since he used it in numerous passages nonchalantly.

In the novel, the white characters not only use the " $n$ " word habitually but also contemptuously. In fact, the only white character who appears to use it innocuously is Huckleberry Finn. For instance, in an early passage Pap Finn openly expresses his bigotry over a black man gaining voting rights. After Pap Finn takes Huck to a hidden cabin, he becomes inebriated and engages in a tirade over the government. He conveys his scorn towards blacks when he relates how 
There was a free nigger there, from Ohio; a mulatter, most as white as a white man...And what do you think? They said he was a p'fessor in a college, and could talk all kinds of languages, and knowed everything. And that ain't the wust. They said he could vote, when he was at home....when they told me there was a State in this country where they'd let that, nigger vote, I drawed out... And to see the cool way of that nigger-why he wouldn't give me the road if I hadn't shoved him out o' the way. I says to the people, why ain't this nigger put up at auction and sold. $(27-8)$

This man Pap is scorning, a mulatto, is half white and half black; yet Pap uses the " $n$ " word in reference to him, and even says that he should be enslaved. Being uneducated himself, Pap Finn is indignant upon learning that this mulatto man has not only been educated but also managed to gain a respectable profession. Pap Finn is indignant at the thought of this man, whom he considers his inferior because of his African ancestry, defined by the one-drop rule of the era, obtaining a higher social rank than he occupies. Pap is unwilling to accept the advancement of the mulatto man. While other characters also use the "n" word with disdain, Pap Finn uses it vehemently, and his belief that blacks should not gain the same rights as whites is an especially offensive passage. Huck does share some of his father's negative Irish characteristics, including this usage of the " $n$ " word in contemptuous contexts. Nonetheless, whether it is used casually or contemptuously, the use of the " $n$ " word was still offensive regardless of the context.

The affective readings of minority readers were disregarded by cultural authorities and journalists despite these concerns. According to Jonathan Arac, literary critics and 
cultural authorities cited three categories in their defense of Huckleberry Finn: irony, realism, and historicism. These three categories were invoked to counter criticism from minority readers. Arac derides these practices, asserting that "[i]t is offensive for cultural authorities to grant legitimacy to only a single way of reading” (Arac 32). In respect to irony, Arac explains that this refers to "the moral stance" the novel takes towards slavery. To illustrate the function of irony, Arac cites the passage where Huck says he will "go to hell" for helping Jim escape, noting that the irony of this passage is that Huck is doing what is "morally correct" and will therefore not go to hell. The irony of the narrative was evident to readers who shared the assumption that slavery was immoral and defines the moral significance in this passage (34). Most critics and cultural authorities, however, employed the two latter categories in defense of the novel. The journalist quoted in the preceding paragraph indeed relies on the categories of realism and historicism to support her stance on the novel. Moreover, she is disseminating a single interpretation of the novel. Arac refutes this argument, noting how “Twain's concern for accuracy in imitating precise dialects does little to ensure that the speakers of those dialects are taken with full seriousness" (38). While Twain's intentions were not to undermine Jim's intellect or that of his other characters, Arac is suggests that Twain did not fulfill his ethical responsibility as a writer. In striving for "accuracy" in vernacular speech, Twain did not consider how diverse readers would respond to the novel. Regardless, even if he had, it was impossible for Twain to foresee how readers would interpret the novel almost seven decades later. 
Criticism over the racial stereotypes in Twain's novel were prevalent and made headlines in the late 1950s and early 1960s. In another article appearing in The Chicago Daily Tribune entitled "Yesterday's History," Theodore Z. Manuel reports that the New York board of education had dropped Huckleberry Finn because “[ $\mathrm{t}]$ he book's description of Negroes contributes to an artificial, prejudged concept of the race, regardless of the child's possible contrary experiences" and goes on to argue that "[t]he positive aspects of the Negroes part in history and society are withheld...Let schoolboards start teaching lessons which include the entirety of historical truths, rather than try to erase embarrassing one sided accounts of historical situation which once prevailed"(Manuel). Like other journalists, Manuel also employs history to support the teaching of Huckleberry Finn in the classroom. Moreover, in the quotation above, which summarizes the reasons the board of education gave, he is sarcastically implying that it is unreasonable for minorities to want the book dropped given that there is a discrepancy between the depictions of race in the book and the actual experiences of children assigned to read the book. Manuel's assumption that a child's experience differs from the book seems improper and negligent. Given that the country was still in the process of desegregating schools, black children certainly were aware of their positions as second class citizens. Similar to the literary critics and journalists commenting on the book's removal, Manuel contends that the novel demonstrates "the positive aspects of the Negroes in history," alluding vaguely to Jim’s "humanity."

Despite being neglected by cultural authorities and literary critics, minority readers persisted in challenging Huckleberry Finn. In response to the article "This the 
Negro Owes Himself," a reader named Louise H. Pack argues against racial stereotypes and the use of the " $\mathrm{n}$ " word. In a letter published in The Christian Monitor, she asserts that:

The word 'nigger' is used today in a derogatory manner...A child is very much impressed by the printed page. When he sees the derogatory term used it puts a stamp of approval on its modern usage...Fortunately, stereotypes do not affect the white American in the same manner that they affect the Negro. Here in America, the former is not judged by what a few might do or say, but is judged on his individual merits.(Pack)

Pack's claims are valid, given the negative connotations associated with the "n" word. Her concern over the impact it has on a child is also valid, given that a child is in a vulnerable position, assuming he or she is in a predominantly white learning environment. Moreover, the "n" word may have been used "habitually" in the antebellum period as critics claimed,, but its meaning was just as derogatory then as it was in Pack's current time. Its modern usage served to reinforce the racist ideology that African Americans involved in the civil rights movement were attempting to disprove. Pack's remarks illustrate that the use of the " $n$ " word in the novel was threatening to the civil rights movement. The institution of slavery had long been abolished; yet the continued usage of the " $n$ " word exacerbated the challenges of civil rights leaders and activists were facing in their fight for equality and desegregation. In the final line, Pack is also countering what the journalist claimed, comparing the criticism of the portrayal of Pap Finn to Jim. She is implying that it is not an appropriate analogy, because the 
qualities of African Americans are assessed more rigidly than whites. Additionally, she is asserting that racial stereotypes harm the positive image that African Americans were attempting to establish, and threatened to perpetuate the negative racial stereotypes that existed during slavery.

Five years later, in 1962, a musical adaptation of the novel generated controversy at George Washington High School, a public school located in San Francisco. In the musical, black students were cast to portray slaves, which was met with opposition from parents, students, and several organizations. The New York Times published an article titled "Report from the Nation: Huck Finn Stirs Race Discord Note" on June 3, 1962, describing the controversy over this musical production of the novel. Organizations such as the National Association for the Advancement of Colored People (N.A.A.C.P.), the Afro-American Association, Inc., the Baptist Minister's Union, and the Interdenominational Ministerial Alliance all protested against school officials who approved this musical. According to the anonymous writer, "[t]he N.A.A.C.P. first talked of picketing, then boycott. It called the musical 'degrading'. The ministerial groups said they were 'shocked' by the aggressive disregard shown by the school authorities for the feelings and sensitivities of the Negro parents and students" ("Report from the Nation: Huck Finn Stirs Race Discord Note"). The director's decision to have black students portray slaves was probably innocuous, but to parents it was demeaning to have their children casted in roles as slaves. If seeing the word on a work of literature "puts a stamp of approval on its modern usage" as reader Louise Pack stated, then being called the " $n$ " word on stage in front of an audience must be equally if not more devastating for a black 
child. Casting black students as slaves conveyed a negative message to minority parents and students. To minority parents and students, the musical implied that they would remain in this subjugated, static "role," not necessarily as owned property but through current laws of segregation. Similar to how critics and cultural authorities reacted to the concerns of minority readers, school authorities were unwilling to understand why parent and students felt affronted. Moreover, it suggested a regression, a yearning for the unpleasant antebellum era while civil rights leaders in the present were working toward advancing equal rights for everyone.

In 1966, minority readers were still burdened by the negative racial stereotypes that Twain was perpetuating in his novel. A group of minority students from the University of Massachusetts, who were highly articulate and well-educated, expressed displeasure with the stereotypical depiction of Jim and, refusing to be silenced, initiated a protest to prevent Twain's character Jim from becoming the quintessence of their race. The students confronted three faculty members in the English department, as well as one African American professor from the history department who was asked to attend a forum. The students made it clear that they did not object to the novel being a classic of American literature, but objected to the way professors were teaching the novel in their classrooms. Joyce Graham, a student participating in the protest, claimed that what they strongly objected to," "is the manner in which the book has been approached by the teachers and the type of image of the Negro being impressed in the minds of uninformed white kids who have had very little contact if any contact with black people"” ("Students Protest Use of "'Huck Finn"”). Graham was reiterating the concerns expressed by Louis 
Pack; however, while Pack focused on the impression the use of the ' $n$ ' word has on a child of color, Graham expressed concern over what uninformed white students were learning from Twain's novel. Minority readers were fearful of the impact Twain's novel was going to have in the short-term on children of color, but also concerned about the long-term consequences since white students were being wrongly educated regarding people of color.

The protests were first covered in the New York Times in a piece titled "Negro Students Protest Reading 'Huckleberry Finn.'” The students' reactions to reading the novel in class are captured in the article. According to one student, "the book gave a distorted image of Negroes" and the article goes on to note that "[t]wo negro girls walked out of a sophomore English class recently when the character Nigger Jim was mentioned" ("Negro Students Protest Reading 'Huckleberry Finn.'”) Arac discusses the article and protest in his book, but states that the event was miniscule compared to the headline (65). The description of the protest in "Negro Students Protest Use of 'Huckleberry Finn"” demonstrates that it was not a minor event, and that the students and English professors engaged in a significant argument. Another student, Carnall Eaton, asserted that " "the book reinforces prejudice, reinforces the belief that all Negroes shuffle, eat watermelon, and giggle." The student is expressing his concern over his race being defined as simpleminded and ignorant. Arac also claims that these two negro students walked out because, in the class, "a racially offensive misnaming was permitted to circulate" (Arac 67). Arac is referring to the phrase "Nigger Jim," which, as I will illustrate shortly, was even used by the student protesters. 
These students who were protesting the novel cited two passages to illustrate how Jim is stereotypically depicted in the novel. The first passage they cite is from the second chapter, where Jim is introduced. The students had this passage on their petition, stating that Jim, whom they referred to as "Nigger Jim" " "is presented in such a way as to evoke derision and ridicule"," ("Students Protest the Use of 'Huckleberry Finn.'”) Arac draws attention to the fact that writers began using the offensive phrase "Nigger Jim" around the time that the Times article " 'Huck Finn' Barred as Textbook by City” was published in 1957, though Twain never used that phrase in his novel (64). In their petition, the students overlooked this crucial detail, and did not replicate the passage accurately. Instead, they wrote "Miss Watson's Big Nigger Jim was setting in the kitchen door" when the original actually says, “Miss Watson's big nigger, named Jim, was setting in the kitchen door" (9). By circulating the phrase "Nigger Jim", writers had succeeded in normalizing its usage. This, however, worsened how the novel was interpreted by minority readers, and disproves the claim that the journalist from The Wall Street Journal, which was discussed earlier, made about how people were more "careful" with the way they were using language.

The other passage that the students cited was when Jim is reunited with Huck in Jackson Island. In this scene, Jim is startled to see Huck since he had heard that Huck had died. It is a passage that the students asserted "evoke[s] derision and ridicule" because Jim believes Huck has returned as an apparition. In the scene, Jim pleads, "Doan' hurt me-don't! I hain't ever done no harm to a ghos'. I awluz liked dead people, en done all I could for 'em. You go en git in de river agin, whah you b' longs, en doan' do nuffn to Ole 
Jim, 'at 'uz awluz yo' frenz” (41). Jim's gullibility and simplemindedness is manifested in a humiliating and offensive manner. Scenes such as this one not only underscore Jim's simplemindedness and ignorance, but also diminishes his credibility as a character. In her monograph Was Huck Black?, Shelley Fisher Fishkin implores readers to read this passage using African-American folklore instead of white minstrelsy as a point of reference. She notes that 'Jim's assertion that he always did all he could for dead people turns out to be consistent with nineteenth-century African and African-American religious traditions" (Fishkin 85). Even if Jim's rituals indeed reflected the religious practices of nineteenth-century African and African-American traditions, this point did not matter to minority readers. Many white readers, as the protesters rightly asserted, were unaware of African-American customs and therefore could not use AfricanAmerican folklore as a framework of reference. Thus, the majority of readers were inclined to interpret Jim's behavior as solely ignorant.

Jim's superstitious nature was another aspect of his personality that was criticized and that cast him as an ignorant character. Fishkin, however, defends Twain's portrayal of Jim. She explains that white slaveholders fabricated narratives of supernatural beings that would wander around the plantations to discourage slaves from running away (83). She insists that the analogy between superstition and gullibility should, "be re-evaluated in the context of how superstition was used by whites as a means of maintaining power over slaves" (84). Fishkin's claims are well substantiated and logical; however, assuming that readers did not have this as a contextual framework in the 1950s and 1960s, there was the risk that the image of the African American man as gullible and unsophisticated 
would prevail. Admittedly, ordinary white and minority readers also did not have access to these literary tools of interpretations. Whether readers have studied literary criticism or not, readers' interpretations are primarily informed by their cultural assumptions. Just because literary critics have been taught how to read literary works does not mean that the readings of ordinary and minority readers are invalid. The sociopolitical context informed readers' interpretations, where minority readers were still subjected to racial discrimination. Although the institution of slavery had been abolished, African Americans were coexisting with white Americans in a system that continued to oppress them. Twain's depiction of Jim as superstitious may have been written with harmless intentions but it reinforced and perpetuated the negative racial assumptions that existed in the antebellum era.

There is another scene, aside from the two cited by the student protesters that underscores Jim's superstition and gullibility. It is a scene where Jim's superstition is again exaggerated and, it too, is capable of evoking "ridicule and derision". In the scene, Huck tells readers how, “Jim said you musn't count the things you are going to cook for dinner, because that would bring bad luck" and afterwards Jim tells Huck that signs of good luck are “ ‘[m]ighty few-an' dey ain’ no use to a body. What you want to know when good luck's a-comin' for? Want to keep it off? Ef you's got hairy arms en a hairy breas', it's a sign dat you's agwyne to be rich"” (44). To minority readers, this passage might be offensive because Jim's superstition makes him come off as unsophisticated. His beliefs lack an explanation, and therefore appear absurd and irrational. White readers in schools would probably take this depiction of Jim at face value and, given that white 
people have been depicted positively in history, as the student protesters claimed, would believe the negative stereotypes ascribed to African Americans. Thus, what was at stake was the prospect of perpetuating a racial ideology that would keep people of color oppressed.

The New York Times published another article titled “'Huckleberry Finn’ Scored for References to Nigger" in 1967. An anonymous writer discusses how a civil rights leader attempted to have the book banned from high school English classes. He states:

[Huckleberry Finn] considered by many the greatest American novel was under attack from a local civil rights leader today because it contains the word 'nigger'. The leader has never read the book through. The Rev. Howard P. Hawkins, former president of the local chapter of the National Association for the Advancement of People of Color, said he had asked that the work be removed from high school English classes...Mr. Hawkins conceded that he had never read "Huckleberry Finn" through, but the Episcopal clergyman said 'I read enough to see the word 'nigger' appear about 100 times (““Huckleberry Finn’ Scored for References to Nigger.")

Even a decade after the initial protests I have examined, writers in the media continued to use the same rhetoric in defense of the novel. Once again, the novel is regarded as "the greatest American novel" and the civil rights leader, like other African American protesters, vilified. Since white liberals identified with Huck and the novel, what was really "under attack" was the identity of white liberals. The writer deliberately underscores that the civil rights leader did not "read the novel through" to undercut his 
criticism. What the writer is implying is that Mr. Hawkins does not understand the "irony" behind Twain's novel, or how it teaches readers how to practice good morals. Mr. Hawkins' full reaction to the novel is also omitted, with the writer briefly quoting him to demonstrate that Mr. Hawkins' did not read the novel closely. Because Mr. Hawkins' read the novel in a cursory fashion, and focused only on the usage of the " $n$ " word rather than on specific passages, the writer is implying that his criticism lacks validity. Thus, Mr. Hawkins is portrayed as an ignorant reader who hadn't read the book thoroughly enough to make any judgments or criticism about it.

Mr. Hawkins may not have read the novel through, but the negative connotations of the " $n$ " word, regardless of the context it was situated in, shaped the interpretations of minority readers. Despite the imposition of a single reading of the novel, it was impossible to reduce passages into a single interpretation given that the novel's language had different meanings for readers. In a key passage from chapter 31, Huck may have chosen to "Go to hell" after deliberating on whether or not he should return Jim to Miss Watson, but his usage of the " $\mathrm{n}$ " word before he decides to spare Jim from slavery makes his "virtuous" act subject to various interpretations. Huck considers several hypothetic reactions from Miss Watson as he debates whether or not he should return Jim to her, then frets as he considers how she may sell Jim, "straight down the river again" and becomes anxious as he thinks about how "[i]t would get all around that Huck helped a nigger to get his freedom; and if I was ever see anybody from that town again, I'd be ready to get down and lick his boots for shame" (Twain 193). Although Huck makes a "moral" decision regarding Jim, this passage is still offensive despite how hasty or 
thorough a minority reader reads it. It is evident from the passage above that, as he examined the consequences scrupulously, Huck was not entirely selfless because he expresses his concern about ruining his reputation.

Critics have claimed that Huck is selfless because of his decision to free Jim, yet he does not demonstrate that he empathizes with Jim's predicament. Furthermore, critics have said that Jim's humanity shines in the novel as a result of the bond he forms with Huck, but Huck does not consider his humanity as he debates whether or not to write to Miss Watson. While he does appreciate how Jim "would always call [him] honey, and pet [him], and do everything he could think of for [him], and how good he always was" (194). Huck only focuses on how well Jim treated him before he tears up the letter he had begun writing to Miss Watson. He does not chose to free Jim because he would again be subjected to maltreatment and exploitation. As dehumanizing as the institution of slavery was, Huck neglects to take account of the abuse he would be sending Jim back into. He also knows that Jim is escaping to be reunited with his family, but Huck does not consider how he would be hindering Jim from reuniting with them. In short, Huck does not really empathize with Jim in this scene since he does not demonstrate any understanding of Jim's circumstances. Because he is young and white, it is perhaps impossible for Huck to place himself in Jim's position. Twain could have made an effort, as a fiction writer and as an antislavery advocate, to identify with his character Jim.

Admittedly, Twain's artistic choices did not make his novel relatable to either minority readers nor writers. In 1979, two decades after the controversies, writer and social critic James Baldwin made a reference to the novel in a speech titled "James 
Baldwin: Witty, Fiery in Berkeley in 1979.” Baldwin mentions how he did not have any writers as models when he was growing up because there were only white writers, and then states that he, "did not agree at all with the moral predicament of Huckleberry Finn concerning Nigger Jim. It was not, after all, a question about whether or not [he] should be sold back into slavery" (Baldwin). Most white writers, of course, wrote about their own social experiences as well as of what they observe in the lives of other white citizens. What Baldwin is suggesting is that, though Twain was a white writer that included a black character in his novel, he did not find Twain to be an adequate model for his own writing. He likely did not find Twain to be an adequate model because of his depiction of Jim, which, as I already discussed, lacked credibility due to his exaggerated dialect and ignorance. Moreover, he is claiming that he disagrees that Huck is in any "moral predicament", implying that Huck should not have to debate whether he should or should not sell Jim back into slavery. Baldwin's critique of this scene is well founded, yet it is interesting to note how he also uses the phrase "Nigger Jim" two decades later. Thus, the phrase continued to be used even by a prominent social critic like Baldwin, demonstrating how the frequent appearance of the " $n$ " word caused readers to misrepresent the novel.

By rejecting or dismissing the concerns of minority readers, cultural authorities, literary critics, teachers, and journalists were silencing them. For his part, Twain could have thought about how minority readers would receive his novel. With a broader audience in mind, Twain could have made other artistic choices to make his novel and his character Jim more relatable to people of color. Nonetheless, unlike other white writers, 
Twain at least included characters of color in his novel. While it does not seem like he fully placed himself in Jim's position, Twain at least made the effort to understand someone like Jim. Similarly, it is imperative for readers in privileged positions to temporarily abandon their own convictions in order to understand the readings of minority readers. It is necessary for readers who have been given the privilege, resources, and education to study a novel such as Huckleberry Finn not to use their power to silence minority readers, but to listen them. 
Chapter 2: Reception of Catcher in the Rye: A Relatable Novel for Teenage Readers, but a Threat to Traditional Conservatives

Praised for its honest portrayal of adolescence in the 1950s, J.D. Salinger's The Catcher in the Rye was particularly well received by teenagers. It was simultaneously rejected by many adult readers, who disapproved of Salinger's depiction of his protagonist, Holden Caulfield. Like Twain's novel, Salinger's was also challenged by readers and subjected to censorship activity. For my analysis of Salinger's novel, I will analyze it amid the emergence of the youth counterculture movement, specifically focusing on its reception in the 1960s. Salinger's protagonist Holden Caulfield became an icon of teenage rebellion, and his novel was eventually adapted by the counterculture movement. Because of the novel's association with the youth counterculture, parents were fearful of allowing their teenage children to read it. As I will show, The Catcher in the Rye was well received by English teachers, high school students and some parents. Readers who opposed the novel viewed Holden's insights and behaviors as a threat to their social values, and, though students wanted to read Salinger's novel, opponents of his novel insisted on banning it from high school reading lists. While minority readers opposed Huckleberry Finn because it reinforced their oppressed positions, readers who opposed The Catcher in the Rye disapproved of Salinger's depiction of Holden, perceiving his immoral behavior and social critique as obstructing their efforts to pass their values on to their teenage children and as encouraging teenagers to participate in the counterculture movement.

In the two decades following the novel's publication Holden's influence on the youth counterculture movement was obvious to parents, who were anxious over the 
influence Salinger's protagonist could have on their teenage children. Though Salinger's novel was published in 1951, years prior to the engendered counterculture movement, Holden's deviance resonated with the aims of the counterculture members. Members of the counterculture movement eventually adapted Salinger's novel, viewing Holden as a paragon of their cause. Holden indeed displayed behaviors that aligned with the movement's aims to subvert traditional American values. Preston Shires alludes to the influence Catcher had in the counterculture movement in his book Hippies of the Religious Right. He discusses how many counterculture artists at the time such as Andy Warhol and Jack Kerouac and Allen Ginsberg from the Beats experimented with unconventional forms of expression in their own work. Shire grouped Salinger's Catcher in the Rye with these artists because of the nonconformist behavior Holden displays (Shire 23). Parents were aware that Holden had become an iconic figure of the movement, and feared that their teenage children would be encouraged to mimic Holden's nonconforming behavior. Their concerns were well founded, given that teenagers revered Salinger's book because they identified with Holden.

To the dismay of many adult readers, specifically parents, Holden was a character that, through their affective reading practices, teenagers identified with because they felt that he accurately depicted their beliefs. Critic Pamela Steinle discusses how teenagers were the group of readers most receptive towards the novel in her book In Cold Fear: "The Catcher in the Rye" Censorship Controversies and Postwar American Character. She observes that teenagers were "the audience most likely to identify with Holden, to find the novel's use of vernacular familiar, and to appreciate the critique of contemporary adulthood" (Steinle 19). Steinle's observation illustrates how teenagers not only related 
with Salinger's protagonist, but also agreed with Holden's critique of adults. Adults felt that Salinger's character would encourage teenagers to imitate his behavior and lack of respect for their social values. Thus, though teenagers asserted that Holden indeed represented their teenage culture, adult readers refused to accept Holden as a paragon of adolescence. Instead, they believed that, if teenagers exhibited any form of rebellion or disrespect for their values, it resulted from reading Salinger's novel.

Teenagers of the 1950s and 1960s were ambiguous subjects for adults, whose perception of their teenage children differed from reality. With many social changes taking place after World War II, teenagers were much more difficult to understand. According to Steinle, there was

a conflict or at the very least a lack of clarity as to what is believed about American adolescents-who they are, how childhood should be portrayed, and what nature of 'world' adolescents should read about and study. The enculturation of children-the teaching (tacitly and explicitly) of values, beliefs, and ideals, as well as explanations as to how to negotiate one's world-is perhaps the greatest charge and responsibility of any society. It is important that what a child is taught 'fits' with cultural behavior and expectations. (Steinle 4)

What Steinle's observations reveal is that adult parents were offended by Salinger's novel because his portrayal of adolescence suggested that they were incompetent parents. Adults may have been uncertain about how their American teenagers should be depicted, but what they did agree on is that Salinger's portrayal of Holden and his views reflected their lack of good parental skills. As a character, Holden did not "fit" with cultural behaviors and expectations. He is a defiant teenager who criticizes American social 
values and the aspirations of American adults. If Holden embodies the behaviors and beliefs of ordinary teenagers, that meant that adult parents were not fulfilling "the greatest charge and responsibility" as members of society. Consequently, they responded by protesting against its status as required reading in junior high and high schools.

In an article that appeared in the New York Times titled "Ban on Authors is Urged Upstate: Salinger, Hemingway and Baldwin Are Attacked" published in 1964, the anonymous journalist discusses how the president of the Vestal Schoolboard Harold C. May denounced The Catcher in the Rye for being a "dirty" novel. In the article, May is quoted as stating that he wanted the censorship to be applied with reasonable control and that it " "should be exercised by the professionals, not by me or anyone else who is not a professional, but exercised within the framework of the philosophy of the members of the school board and the parents of the children"" and added he that "the secondary school system [is] populated by children whose minds are being molded and whose ideas, principles, and values in life are in a developmental stage is a microcosm" ("Ban on Authors is Urged Upstate"). May's statements illustrate that educational "professionals" were supposed to be the ones in charge of regulating censorship. Moreover, they illustrate that only the opinions of those in authority positions were taken into account. What this suggests is that teenage students, the ones who would be studying the reading material, were excluded from this dialogue. It is also crucial to note that in the latter part of his statement, May recognizes that as a social institution, the secondary school system is an environment contributing to the moral development of children. May's statements reveal how students' opinions were not consulted and that censorship activity was determined 
by how well the material aligned with the philosophies of parents and school board members.

Nonetheless, teenage students had their own opinions about Salinger's novel. In "Literary Controversies", an article published by the Los Angeles Times in 1964, two high school honor students explain why they advocate reading the book. The students were Shelley Zellman and Ellen Maddow. According to Zellman and Maddow, Salinger's novel “exposes delicately the perilous moment when a person stands, unmoving, at the end of the bridge of youth, hesitating to take his first step onto the more stable ground of adulthood" and they argue that, "[t]he book has been recommended by many English teachers, and by our parents as well, and we hope that our classmates will not be denied the privilege of reading and discussing this fine and, in our opinion, extremely educational classic" (Maddow and Zellman). Maddow's and Zellman's statement demonstrates that while many adult parents disapproved of Holden's critique of adulthood, teenagers identified with his anxieties over growing up. Adult parents, however, focused solely on how Salinger's book reflected their incompetence as parents. Rather than attempting to understand their teenagers' sense of isolation, they assumed that the best course of action was to ban the book. Furthermore, Maddow and Zelman's article underscores how teenagers fretted about the responsibilities that adulthood entailed. In the second half of the quote, Maddow and Zellman candidly advocate Salinger's novel, noting that their own parents and English teachers recommend it. This demonstrates that parents had disparate perspectives about what their children should be learning. Their appeal demonstrates that there were some adult parents who recognized the literary merits of Salinger's book, and who were making an effort to empathize with 
the person who "stands, unmoving, at the end of the bridge of youth" to adjust into adulthood.

A passage from chapter twenty-two may have resonated with teenagers like Maddow and Zellman. In this passage, Holden exhibits dismay at the prospect of becoming an adult, fearing that he will also become a narcissist concerned with social status. As he is conversing with his ten-year old sister Phoebe, Holden conveys his fear when she suggests that he become a lawyer like their father. He tells Phoebe that a career as a lawyer does not interest him because lawyers do not save "innocent guys" lives" and states that

All you do is make a lot of dough and play golf and play bridge and buy cars and drink Martinis and look like a hot-shot. And besides. Even if you did go around saving guys' lives and all, how would you know if you did it because you really wanted to save guys' lives, or because what you really wanted to do was be a terrific lawyer, with everybody slapping you on the back and congratulating you in court...How would you know you weren't being a phony? (Salinger 223-4) Holden's concerns in this passage reveal that he is afraid of yielding to materialistic values. In fact, he is unsure if he would have the capacity to self-reflect on his own motives as an adult. Parents who objected to Salinger's novel perceived Holden to be immoral, yet Holden is subtly implying that it is adulthood that fosters unprincipled human beings. He is hesitant to transition into adulthood because he recognizes that the adults are primarily concerned with having a high social status. Holden is critiquing capitalism for encouraging the narcissism of adults and making them more concerned with their social positions than the well-being of others. In the passage above, he is 
claiming that those that pursue such a prestigious profession only do so with the objective of acquiring material wealth, and not out of a genuine interest in helping their clients.

Steinle suggests that American adults of the era were not consistent in upholding the traditional values and ideals of the country. According to Steinle, "[ $\mathrm{t}]$ he greater difficulty in the post-World War II period, however lies in the ever-widening distance between traditionally held American ideals and values (democracy, freedom, individualism, equality, voluntary social responsibility) and the actual behaviors and expressions of Americans" and Salinger's novel "reads as a recognition of America's own process of maturity, from innocent and idealistic 'childhood' to the 'adult' pursuit of status and power in both our private lives and as a nation" (Steinle 4). Holden's criticism of a lawyer's unethical intentions illustrates his disillusion with Americans and their inability to adhere to the traditional ideals and values. In his example of the lawyer, Holden pinpoints the discrepancy that exists between traditional American values and the actual behaviors of American citizens. Of the values that Steinle enumerates, Holden seems particularly focused on voluntary social responsibility and how a lawyer, being in such a prestigious position, is more concerned with displaying his or her status instead of honoring his duties to other American citizens. Teenagers who identified with Holden probably experienced the same concerns he did about maturing. While American parents felt that their social identities were being affronted by Holden's social critique, teenagers found his criticism insightful because they were grappling with their own identities in the face of an uncertain future.

Not all adults feared the implications of this aspect of Holden's narration. There were school board and faculty members who advocated for Salinger's novel and who 
attempted to have it approved on reading lists. In an article published in the Los Angeles Times in 1964 titled "Uninhibited Book Stirs School Board Turmoil: Classroom Ban on 'Catcher in the Rye' Provokes Sharp Debate Over Censorship" by Dick Turpin, the Times education editor, informs readers about the disagreements among school board members regarding Salinger's book. A scheduled classroom panel to discuss Salinger's book by a tenth grade English teacher initiated an impromptu review by two board members. Charles R. Smoot, a board member, informed the superintendent Jack P. Crowther that the book was not on the list of approved readings, and called the book "trash" because it contained "“four-letter words not fit to be inside a privy wall!"” (Turpin). An advocate of the novel, Crowther responded by demanding that, "the book be reviewed for possible placement on the high school list" (Turpin). Given that readers' interpretations are influenced by their values, the polarized interpretations of the novel among school board members underscores how the various values of Americans conflicted. Salinger's novel had a polarized audience in American adults. On the one hand, Salinger had a conservative audience who did not see any educational value in teaching the novel; on the other hand, he also had an audience who was more receptive and willing to include the novel in reading lists. Though Turpin does not include a direct statement by advocates of the novel, he reveals that students were the ones who had requested to discuss the novel in class. Students in this article are again depicted as having a favorable opinion of The Catcher in the Rye. In contrast to the parents who were averse to Catcher, Turpin notes that a tenth grade teacher, "was unidentified but a school official said students had asked her for approval to have the discussion and she had granted it" (Turpin). What this illustrates is that while some teachers and board members were willing to allow students 
to choose the reading material they wanted to study, others were reluctant to endow students with this kind of autonomy. The coarse language in the novel made it difficult to grant students the autonomy to analyze and discuss Catcher in the classroom.

Opponents of Salinger's novel frequently cited Holden's use of profanity as a reason to remove it from reading lists. Smoot's primary critique, for example, was that the novel contained four-letter words that were inappropriate "inside a privy wall". Of course, the "privy wall" Smoot is referring to is the school classroom, suggesting that Salinger's work is inappropriate in a space designed exclusively for the exchange of knowledge. He cites the four-letter words that appear throughout the novel as a sufficient reason to ban the book, though subconsciously he may have a different reason for his disapproval of the novel. Steinle notes that, "Catcher's offensive nature is not sufficient in itself to explain the apparently endless nature of the debate. Its lengthy continuation is actually fed by an avoidance of deeper issues and an inability, by participants for and against Catcher, to understand or articulate exactly what is at stake" (Steinle 3). In postWorld War II America, what was at stake was the possibility of the beliefs, institutions, and social values being toppled by participants in the counterculture movement. Smoot's concern, then, reflects a general, deep-seated anxiety over the future of the country if the succeeding generation adopted contradicting ideologies.

Since opponents of Salinger's book could not admit nor articulate their underlying anxieties, Holden's incessant swearing was an acceptable reason to have it banned. In the opening scene of the novel, Holden begins using crude language. He instantly conveys to readers that he is speaking to a psychotherapist in a mental institution. Holden tells this primary audience that he or she is probably expecting him to speak about what his "lousy 
childhood was like, and how [his] parents were occupied and all before they had [him], and all that David Copperfield kind of crap", and then says that his parents would have "two hemorrhages a piece if [he] told anything pretty personal about them" because they are "nice and all...but they're also touchy as hell" (Salinger 3, original emphasis). Holden frequently uses obscene words such as "crap", "hell” and even "damn" throughout the novel. These were almost certainly the four-letter words that Smoot was referring to, though underneath the surface there appears to be more that is disquieting about this opening scene. The fact that Holden, a sixteen-year old teenager, is receiving treatment in a psychiatric hospital probably upset many American parents. They likely interpreted this scene as reflecting their own failure to provide a secure environment for their teenage children's mental health development. Furthermore, Holden's sarcastic tone towards his parents also seems likely to have alarmed parents. American parents probably felt that Holden's behavior would encourage their teenage children to engage in the counterculture movement and rebel against them. His use of offensive language simply served as a justification to have the book banned.

Despite his use of offensive language, Holden is discreet about using highly offensive terms. Critic Daniel Costello discusses Holden's foul language and the fact that he actually seems to refrain from using stronger terms. In his essay "The Language of 'The Catcher in the Rye"', Costello notes that, "Holden's restraints help to characterize him as a sensitive youth who avoids the most strongly forbidden terms, and who never uses vulgarity in a self-conscious or phony way" (Costello 175). Holden's discretion and, on two occasions, attempts to erase the profanity written by others illustrates that, though he is interpreted as a defiant character by a majority of readers, he still exhibited a moral 
conscience. In fact, his choice to refrain from using stronger obscenities demonstrates that there were regulations that he adhered to. Costello asserts that his self-restraint was typical of prep school boys, but this aspect of Holden's character demonstrates how he is a multifaceted character. In a cursory examination of his character, Holden can be interpreted as a rebellious and lacking morals. However, although he rejects the moral codes of adults, his introspections reveal that he is not an amoral character. Viewing the innocence of children as pure, he makes it his objective to preserve it.

On the verge of adulthood, Holden recognizes that he has lost his innocence, but he strives to preserve the innocence of younger children. As Steinle observes, Holden attempts to erase offensive language twice from the walls of an elementary school. In this scene, Holden sits down on a flight of stairs to gain his composure, and notices that somebody had 'written 'Fuck you' on the wall. It drove [him] damn near crazy. [He] thought about how Phoebe and all the other little kids would see it, and how they'd wonder what the hell it meant... and how they'd all think about it for a couple of days" (Salinger 260). Despite his own vulgarity and cynicism, Holden exhibits concern over younger children being exposed to strong, coarse language. He doesn't seem to want Phoebe and the other children her age to learn what such a word means out of fear that it will distress them. Furthermore, he is concerned that they will lose their purity, or innocence, if they become aware of what this word means. Afterwards, he admits that he was "afraid some teacher would catch [him] rubbing it off and would think [he'd] written it. But [he] rubbed it out anyway" (261). Holden erases the "Fuck you" written on the wall to preserve the innocence of the children, possibly because he does not want them to succumb to the immoral and egoistic values held by adults. American adults who were 
against to the novel, however, were focusing solely on Holden's defiance towards traditional American values and overlooking his benevolent nature.

Salinger depicts the values of teenagers as innocent and pure in contrast to adult values; however, receptive readers conceptualized Salinger's theme of innocence differently. In an article published by New York Times on April 7, 1963 and titled "They Speak the Teen-agers Language," written by David Boroff, he focuses on the commonalities between Salinger's book, William Golding's Lord of the Flies, and John Knowles A Separate Peace. Boroff observes that these novels are connected by their themes of innocence and the loss of that innocence, and he discusses how teenage readers interpreted these themes. Boroff asserts that readers, "avert their gaze from the sullying of innocence. They are steadfast in seeing childhood as pure but beleaguered by a corrupt and corrupting society. The ceremonies of innocence are frequently stained, but youthful integrity is never really undone. The proper relationship to the adult world is a mixture of pity and contempt as in "The Catcher in the Rye"' (Boroff). To many readers, innocence is not a quality that children lose. Rather, it is a quality that is redefined as children mature. As children mature, they are gradually gaining new insights as well as a new sense of self. Holden may have viewed childhood values as "pure," but readers had a different perspective. Through Holden's point of view, teenage readers became conscious of how their "pure" childhood is already contaminated and being changed by the corruption of the adults in society. Boroff asserts that teenagers have a "mixture of pity and contempt" for adults because of how self-conscious and narcissistic those adults become. These insights are what made readers, specifically Salinger's teenage audience, appreciate his book. 
Nonetheless, American adults persisted in challenging Salinger's novel. In an article titled "Salinger Book to Remain on Reading List" and published in the Los Angeles Times on February 27, 1964 titled "Salinger Book to Remain on Reading List," the anonymous author discusses how a group of citizens protested against Catcher. An issue that came up during the protests was the scene where Holden meditates on his sexual inexperience. According to the author of the article, the protest group called the novel "filthy" and had "Mrs. Basil Denison, spokesman for the protest group, read passages from the book relating to sex experiences but admitted she had not read the whole work" ("Salinger Book to Remain on Reading List"). Although I contended in my previous chapter that the interpretations of minority readers should not be dismissed just because they had not read Huckleberry Finn entirely, given that the minority are teenagers in this context, I believe that adults protesting Salinger's novel should have read it thoroughly before deeming it "filthy." While people of color have experience with racial oppression, adults may not understand teenage isolation or they simply do not remember experiencing it. Rather than focusing only on the perverse passages in the novel, protesters should have considered how teenage readers connected with Holden's sense of isolation. They should have considered how high school students could study the novel to grasp a new understanding of their positions in society.

In this article, the author implied that protesters were arguing that the novel was indirectly encouraging youths to contracting a sexually transmitted disease; however, their arguments were not persuasive enough to have the book banned. Protesters suggested that the scene that Mrs. Denison read aloud would encourage high school students to engage in illicit sex and catch a venereal disease. According to the anonymous 
writer, "[d] espite charges that the book will promote venereal disease among high school youth, the school board voted that selection of recommended reading should be left up to teachers" ("Salinger's Book to Remain on Reading List.") The school board's vote demonstrates that they were not persuaded by the protesters' arguments and again preferred to rely on the judgment of teachers in selecting the readings. In the scene that Mrs. Denison read aloud from chapter thirteen, Holden has an encounter with a prostitute in his hotel room. However, while Mrs. Denison's and the protesters' concerns are understandable, the scene only underscore Holden's self-consciousness over having to engage in this "adult" activity. In this scene, Holden tells readers that he "knew I didn't have to get all dolled up for a prostitute or anything...I was starting to feel pretty sexy and all, but I was a little nervous, anyway. If you want to know the truth, I'm a virgin" (Salinger 120). His thoughts about engaging in sexual intercourse illustrate that he is a self-conscious teenager with anxieties over something he is inexperienced with. He admits afterwards that he "could get in some practice with her in case I ever got married" (Salinger 121). It is understandable that readers opposed to the novel were alarmed by this scene depicting a sixteen-year old boy planning to engage in sexual intercourse with a prostitute. Holden's subsequent remark, however, demonstrates that he is an adolescent boy concerned about marriage, a social institution belonging to the adult world. Knowing that he is about to transition into adulthood, Holden already feels pressured to gain sexual experience. Thus, though Salinger's novel is transgressive, as a fiction writer he chose to depict Holden like this to illustrate the ingenuity of how teenagers perceived the adult world. In fact, when read and analyzed carefully, this scene divulges how teenagers were grappling with their insecurities and sense of self. 
American parents, however, continued to focus on the transgressive nature of the novel, and disagreements over the literary merit of Salinger's book persisted. In an article published on April 5, 1964 in the Los Angeles Times titled "Trustees Decline to Ban Book: Schools to Keep 'Catcher in the Rye' Despite Protests," the anonymous author informs readers of the measures taken by Bert East, a parent of two students that attend Glendora High, to have the book removed from the school library. East contended that the book "contained numerous smutty passages and was a book of filth" but the Superintendent W. Del Walker asserted that the request was denied because "no responsible group had recommended its elimination from public libraries"("Trustees Decline to Ban Book: Schools to Keep 'Catcher in the Rye' Despite Protests"). East may have argued that the passages in the novel were filthy as a reason to have it banned, but Steinle's observations demonstrate that East's primary concern, like that of the majority of American parents, was to protect their own egos and to prevent their teenage children from being influenced by a counterculture icon like Holden. Later in the article, the anonymous writer reports that East brought in two organizations to review the book and make Walker reconsider having it banned. In addition, East had mimeographed obscene passages and attempted to distribute them at a board meeting, but was stopped by police. East's efforts and Walker's initial denial to have the book banned underscores, again, the polarized reactions to Salinger's novel. American parents, in particular, were the ones who appeared the most threatened by Catcher.

Throughout the country, there was an evident pattern occurring; when parents protested, school board members tended to defend teachers who included Catcher on their reading lists, and to disregard the arguments made by parents. In another article that 
appeared in The Christian Science Monitor in 1965 titled "Guns Bombard Student Readings, staff writer Lucia Mouat informs readers of a protest that took place in Waterford, Connecticut. Board members gave the verdict that " $[t]$ eachers have the right to draw up their own required and recommended reading lists," which is similar to what Mrs. Denison's protesting group was given (Mouat). Teachers were not only entrusted with the reading lists, but their judgments were valued over the opinions of parent protesters. After school board members affirmed that teachers have the right to select what books they assign, fifteen parents reacted by partaking in plans to build a separate school. According to Mouat, "Since they felt the cost of and technical difficulty of starting a high school would be too great, they settled for an elementary school-a 'nondenominational Christian day school" "which would give "youngsters a strong grounding in Biblical teachings, as well as academic work they hoped to 'fortify' them for the type of reading they would face later on" (Mouat). Because they could not persuade board members to ban Salinger's novel among others they considered inappropriate, they decided that they would open this Christian school and "fortify" their children by embedding Christian doctrines in their early education. These parents seemed to believe that teaching children bible lessons at an early age would entrench their values, making their children less likely to become corrupted by novels such as Salinger's.

These parent protesters who wanted to instill Christian doctrines on their children were likely appalled by Holden's frequent blasphemies and jeers towards Christianity. Steinle discusses how the parents cited the profanity in the novel as a reason to have the book censored. Specifically, parent protesters objected to Holden's use of "goddamns" and "chrissakes." Steinle replicates the statement from Kristen Keefe, a resident from 
Marin County: “'God's name was taken in vain”” (Steinle 118). Keefe counted a total of 295 occasions in which Holden uses obscene language that is disrespectful towards God and Jesus Christ. (Steinle 118). Holden indeed uses profane language that invokes God's name early on in the novel. In chapter three, Holden begins his narration by telling readers that he lied to his teacher Mr. Spencer about his bag because he doesn't "even keep [his] goddamn equipment in the gym" (Salinger 22). Afterwards, he begins criticizing a former Pencey student named Ossenberger, who has dorm buildings named after him because he donated a large sum of money to the school. He mocks a speech that Ossenberger delivers in which he advices Holden and other Pencey students that they "should always pray to God-talk to Him and all-wherever we were. He said he talked to Jesus all the time. Even when he was driving his car. That killed me. I can just see the big phony bastard shifting into first gear and asking Jesus to send him a few more stiffs" (Salinger 23, emphasis original). To religious and conservative readers, Holden is not merely mocking Ossenberger; he is taunting Christian beliefs. Moreover, by calling him a "phony bastard", he is denigrating Christian beliefs and implying that Christian worshippers are hypocrites. It is understandable that Christian parents were offended by this passage. Nonetheless, I believe that what Holden is really criticizing is the contradictory behavior of the individual rather than the institution of religion. Holden is a paradoxical character who, despite his pessimism and use of profanity, acts according to his own sense of what is right and wrong.

Besides arguing that the novel contained too much profanity, many protesters continued to argue that high school students were too young to read Salinger's novel while some kept questioning its literary merits. In her article, Mouat relates to her readers 
how Reverend Duane F. Sweet, a pastor from Waterford's Lake Pond Baptist Church, argued that high school students were not old enough to study Salinger's novel. Sweet conveys his concern with the age group involved, arguing that "if these were college students it would be different. People are just not grown up at 14" (Mouat). The pastor is suggesting that, at the age of 14 , adolescents are not intellectually or emotionally developed enough to study it as a literary work. However, he then states that he has "read "Catcher in the Rye"' and other portions of most of the others, and they don't have the character of great works if you take away the curse words and obscenities"' (Mouat). In his first statement, Sweet implies that Salinger's book is just not fit for 14-year old adolescents, but here he is claiming that Salinger's book lacks the element that makes literary works significant. His claim that Salinger's book does not "have the character of great works" is vague; his argument may have been more persuasive if he would have specified what Catcher is lacking or articulated what "character," in his opinion, makes a work of literature great. Furthermore, he is suggesting that the popularity of Salinger's novel is due to the profane language and obscene passages, denigrating its status as a literary work. Unlike other readers opposed to Salinger's novel, Sweet's criticism is not directed at the language per se. By "character," the pastor could be referring to the morals being conveyed in Holden's narrative. The pastor still, nonetheless, conveys his apprehension over the effects that the novel could have on teenage readers. Similar to most protestors, his focus is on the immoral aspects of the novel, and his concern that it is not "fit" for younger adolescents underscores his fear over Holden's influence on them. Like other readers, he does not grasp why teenagers identify with Holden, and he therefore interprets Salinger's work unfairly. 
An initial (or in some cases, partial) reading of Catcher left many of these readers with an unfair interpretation of Holden. He is a complex character who does manifest a moral conscience, though he also seems to have a disdainful attitude towards girls and women. In the passage with the prostitute, Holden concedes that he has never copulated because he always listens to girls when they tell him to stop. He tells readers how, unlike other male teenagers his age, when girls tell him to stop, “I stop. Most guys don't. I can’t help it. You never know whether they really want you to stop...[t]he trouble is, I get to feeling sorry for them. I mean most girls are so dumb and all. After you neck them for a while, you really watch them lose their brains. You take a girl when she really gets passionate, she just hasn't any brains" (Salinger 120-1). Holden indicates that he has a good moral conscience by conceding that he does not force a girl into having sex.

However, he also belittles girls by stating that when they get really passionate they do not act rationally. Afterwards, when he sees Sunny remove her dress, he refuses to sleep with her and admits that watching her take it off made him feel "much more depressed than sexy," and he belittles her by stating that he could not "ever do it with somebody that sits in a stupid movie all day long” (125). The superintendent Mr. Walker most likely disregarded Mr. East's concerns because, though Holden appears with a prostitute in this scene, he chooses not to have sex with her. Holden's attitude toward girls is sympathetic, yet he is simultaneously patronizing. While Mrs. Denison and Mr. East's concerns are understandable, their reading of Salinger's novel was superficial. The in-depth access that Salinger provides to Holden's psyche in this passage reveals Holden's views towards sex and women, which readers should have been discussing. However, readers who opposed the novel were focusing more on what happened in the scenes rather than on what Holden 
was conveying in his interior monologue. Instead, readers against the novel were focusing on passages they considered sordid and which undermined their social values.

Amid the debates of adult readers, teenagers still attempted to insert their voices into the conversations over book censorship. In another article titled "Students Ask Why Books Were Banned at San Marino High” published on January 22, 1970, in the Los Angeles Times, Jack Birkinshaw discusses how high school students demanded to know the reason why certain books were being banned. Birkinshaw notes that Salinger's novel was among the books banned from being sold at a new book sale, which elicited the request from the students. He informs readers that "if certain books are going to be banned at San Marino High School, the students want to know why." (Birkinshaw). Afterwards, he quotes a statement made by Dr. Kenneth Bullock, the school principal, regarding Catcher. Bullock had claimed, "Many communities have been blown apart over that book..I am not about to have it happen here"; students, however, "urged that when books are banned, a small explanation in writing be given" (Birkinshaw). Dr. Bullock may have felt that his decision to ban the book was in the best interest of the community, but like other administrators that objected to Catcher, he is excluding a group (minority readers) whose voice is equally as crucial as that of experts and authorities in charge of banning books.

Birkinshaw's article, as well as others that were examined earlier, demonstrate that parents, administrators, and other groups that objected to Salinger's novel were hesitant to address the racy scenes with their teenage children. Besides the passages where Holden relates his sexual experiences, another passage that readers probably found unacceptable was the scene where Holden suggests that Mr. Antolini, his former English 
teacher, made what Holden views as a sexual advance on him. In this scene, Holden wakes up in panic after he feels Mr. Antolini patting his head, noting that this incident made him, "so damn nervous. I know more damn perverts, at schools and all, than anybody you ever met, and they're always being perverty when I'm around" (249, emphasi original). Holden's insinuation that Mr. Antolini was making sexual advances on him must have disturbed conservative readers. Specifically, the group of readers most distraught by this passage were probably parents. Parents most likely were upset over the ambiguity of this scene, and Holden's assumption that Mr. Antolini's was a "perverty" homosexual. Critic Duane Edwards analyzes Holden's relationship with Mr. Antolini in his essay “Holden Caulfield: Don't Ever Tell Anybody Anything”. According to Duane Edwards, readers must believe Holden's assertion that Mr. Antolini is touching him in the dark, but he observes that, "what Mr. Antolini's intention was we cannot know since even Holden is confused"(Edwards 560). Holden exhibits distrust in general towards adults throughout the entire novel, which likely means that his preliminary assumptions of Mr. Antolini may be untrue. Nonetheless, Holden is still speaking unfavorably about adults and suggesting that they always have malicious intentions. I'll reiterate that their concerns were understandable, but parents still should have attempted to understand why their teenage children found Salinger's novel to have literary merit.

To conclude, parents and school administrators should have been more empathetic towards teenage readers and their affective reading practices. Considering how the sociopolitical climate during the 1960s elicited a sense of isolation and uncertainty in them, Salinger's protagonist enabled them to make better sense of their positions in their communities. Instead of hastily rejecting Catcher in the Rye, parents 
should have read it thoroughly to understand why their teenage children revered Salinger's work and deemed it an "educational classic". Furthermore, teenage children should have engaged in dialogue with their parents and in school board meetings to contribute to the censorship discussions of Salinger's book. The judgments of teenage children were neglected and undervalued by authorities and experts. Inviting teenage students will surely prove to be useful in future controversies, where they can articulate what they believe will be most instructive to read in their English classrooms-or at least to understand the reasons for excluding books of interest to them from reading lists. 
Coda: Polarized Readerships and Strategies to Defuse Controversies

The fluctuation of sociopolitical contexts makes the reception of novels unpredictable. Both Twain and Salinger had a polarized readership, with a segment of readers extolling their novels and another segment waging protests to have these same novels banned. These case studies demonstrated that it is necessary to rely on the expertise of English teachers. English teachers know how to analyze literature and, though their selection of readings is inevitably subjective, they can be trusted to assess the educational merit of literary texts. Literary critics should also be relied upon for their judgment and critiques of novels. However, the case of Huckleberry Finn proved that relying on experts can be oppressive and detrimental if minority readers are being silenced. Had the school boards given voice to minority readers, perhaps the controversies surrounding Twain's novel could have been mitigated. Similarly, in the case of Catcher, parents and school boards should have invited teenage students into the conversation before attempting to ban the novel. My case studies on Huckleberry Finn and The Catcher in the Rye have led me to conclude that providing a venue for dissenters to voice their objections, reaching out to the experts, and inviting students who will be studying the material to contribute in the dialogue of censorship activity are effective strategies for defusing controversies. Using Alison Bechdel's graphic memoir Fun Home, published in 2006, this coda will discuss how applying these strategies can help participants address and defuse future controversies.

In her graphic memoir, Bechdel recounts her childhood in rural Pennsylvania up until her early adulthood, focusing on her conflicting relationship with her father Bruce 
Bechdel. She relates how distant her father was from their family, and how often she and her father clashed because he was always trying to force her to conform to her biologically ascribed gender. She relates how her curiosity led her to research that made her realize that she was a lesbian, and how she struggled to come to terms with this vital aspect of her identity. When Bechdel decides to tell her parents that she is a lesbian, her father commits suicide two weeks later. Bechdel suspects that she may have caused him to commit suicide, and she grapples with this possibility while still trying to come to terms with her sexual orientation. She later learns from her mother that her father was a closeted homosexual, which triggers more perplexed feelings.

Receptive readers have appreciated how Bechdel combined serious themes with humor. Author Chip Kidd of The Cheese Monkeys commented that the novel's "detailsvisual and verbal-emotional and elusive- are devastatingly captured by an artist". Banned books have their own unique qualities that cause disagreements, and Bechdel's visual details is one of the chief qualities that readers have responded to.

Nevertheless, Bechdel's use of visual rhetoric, more than the language in her book, is very problematic. Chip Kidd may have appreciated her visual details, but other readers were appalled by them. Student Brian Grasso from Duke University wrote an article published in the Washington Post explaining why he disapproved of the novel. Grasso shares how he interpreted Bechdel's visual rhetoric, and explains that he is not against the ideas presented in Bechdel's work, but rather against the straightforward depiction of those ideas. He argues that " there is an important distinction between images and words. If the book explored the same themes without sexual images or erotic language, I would have read it. But in the Bible, Jesus forbids his followers from 
exposing themselves to anything pornographic" (Grasso). Unlike Chip Kidd, who was receptive towards Bechdel's visual rhetoric, Grasso is affronted by it. To Grasso, Bechdel's visual rhetoric is pornographic rather than insightful. He is a conservative reader who interpreted her visual rhetoric as pornographic because of his Christian faith. He also posted his comments about Bechdel's book on Facebook, where he was criticized by Fun Home advocates. Although he admits that he did not read the entire book, his strong religious beliefs are a part of his identity that is being challenged by Bechdel's visual rhetoric. His experience is similar to Twain's minority readers who, like Grasso, disapproved of Twain's novel without fully reading it. Grasso presents his conservative views in a sensitive manner, which should have been respected by liberal readers, but was not. Similarly, Twain's minority readers were affronted by Twain's use of the "n" word and his negative depiction Jim, which makes their affective reading of Twain's novel understandable. Though minority readers of Twain's novel and Grasso did not read the respective texts fully, their affective readings of Twain's and Bechdel's novels should not have been dismissed out of the hand.

Readers who opposed Twain's and Bechdel's work perused through these authors' books without reading them fully, and their judgment of these books were informed by their affective readings. The literary evaluations of critics was invoked during the controversies surrounding Huckleberry Finn to justify its place in the required reading list. White liberal readers reacted to minorities' affective readings as though they were insufficient means of interpreting a literary text. They quickly relied on the interpretations of literary critics to dismiss the concerns induced by the affective readings of minority readers. It was unjust of white liberals to dismiss this manner of interpreting a 
text. Grasso's affective reading of Bechdel's visual rhetoric has also been dismissed. Considering that Bechdel's memoir involves visual rhetoric, it is inevitable that conservative readers like Grasso would respond affectively before reading her text carefully. When it comes to handling protesters who want to ban a book because its content offends their social identity and values, it is necessary to validate these readers' interpretations through acknowledgement. The different interpretations of Twain's use of the " $n$ " word should have been discussed by all of Twain's readers. For the future, in handling Fun Home or other book controversies, it is first necessary for affective readings of texts to be considered as a crucial aspect of studying literature. While there are literary scholars such as Rita Felski in her book The Limits of Critique, who discuss the significance of affective readings in conjunction with literary critique, it is necessary for teachers and administrators to consider how boycotts to ban books are motivated by affective readings. Literary works and their aesthetic qualities will inevitably elicit emotional responses that contribute to the meaning of the text. Grasso's affective response to Bechdel's sexual images contributes to the meaning of the text, and recognizing this will be a good place to start defusing controversies.

Moreover, after acknowledging the affective readings of protesters, school board members and administrators should provide dissenters with a venue to voice their objections. Similar to how the students from the University of Massachusetts were given an opportunity to gather English faculty members together to voice protest against Twain's novel, protesters of Fun Home should be given the same opportunity. Protesters should be encouraged to conduct peaceful protests where they can communicate their affective reading of Bechdel's text. The high school students in my first chapter of 
Huckleberry Finn organized a peaceful protest where they voiced their concerns about the negative impression that the novel conveyed about their race. Conservative readers should be granted the same opportunity. They should be allowed to voice their concerns about the sexual images in Bechdel's memoir and explain why they believe that the book should be removed from required reading lists. It is also crucial for dissenters and faculty to discuss whether students disturbed by Bechdel's book should be exempt from reading it. Dissenters should consider whether or not students disturbed should not have to read the book, or if the definitive solution is to ban Bechdel's book.

To have a fruitful discussion of Bechdel's novel, liberal readers should be open to the arguments made by conservatives. Author Paula Young Lee refers to Grasso's Facebook comments on the novel in her article "Students Protesting Bechdel's 'Fun Home': How Clinging to 'Christian Moral Beliefs' Can End an Education Before it Even Begins.” She responds defensively to Grasso's views on Bechdel's novel, similar to how white liberals responded to Twain's minority readers. She asserts, "Too often, it seems to be forgotten that higher education exists to serve knowledge, not to reinforce faith or confirm untested beliefs. A test which these students will hopefully learn should they attempt to open their minds" (Lee, emphasis hers). Throughout her article, Lee presents a good argument in support of assigning Bechdel's book in English classes; however, here she is not exhibiting the open-mindedness that she is arguing for. Like Twain's white liberal readers, she is dismissing the concerns of dissenters. Furthermore, her comments on religious faith are dismissive. African Americans were the minorities in the controversies of Huckleberry Finn, and in Fun Home the dissenting readers are conservatives. Grasso's voice was heard, but his message was not met with understanding 
by liberals. Like Twain's white liberal readers who condescendingly stated that minority readers did not know how to "read a good book," Lee is belittling the religious beliefs of dissenters by implying that their Christian beliefs are not valid or founded on knowledge. In this situation, liberals could try to be more empathetic towards conservative readers, regardless of their own views towards religion. Religious beliefs should be respected, though Young may have made these comments because of how individuals that have identified as Christian have misused this religious faith.

Although Christianity has been used to justify bigotry, and is still used that way by some individuals that identify as Christians, conservative student Grasso provided a sound argument for opposing the novel and made it clear that he was willing to engage with Bechdel's ideas if it weren't for the sexual images she included in her book. Furthermore, he did not use his Christian faith to justify bigotry towards homosexuals and did not convey any intolerance towards Bechdel's lesbian identity. It is necessary for liberals to understand that Christianity is an integral part of conservative readers' identities, and they should listen to conservatives to understand their interpretations of Bechdel's memoir.

Like Twain's and Salinger's readerships, Grasso's and Lee's responses illustrate that Bechdel's audience is also polarized. A segment of her readers have praised Bechdel's novel. Her novel has been recognized as a critically acclaimed novel and even won the Stonewall Book Award-Israel Fish Nonfiction; however, her memoir has caused a lot of controversy. Inside Higher Ed. editor Scott Jaschek wrote an article titled "S.C. House Keeps Financial Penalty of Gay-Themed Book" relating how the South Carolina House of Representatives cut funding from the College of Charleston as a punishment for 
allowing teachers to assign Bechdel's novel. According to State Representative Garry Smith, the novel "'graphically shows lesbian acts" " and is promoting " "the gay and lesbian lifestyle"" (Jaschek). These comments are akin to the ones that were made by Catcher's protesters. Like Catcher's protesters, Smith is against Bechdel's novel because he interpreted it as promoting perversion. Smith is another conservative reader like Duke University student Grasso, but unlike Grasso’s justification for disapproving of the novel, Smith's comments are aggressive and homophobic. Jaschek also reports that the president of the College of Charleston P. George Benson released a statement asserting that, “"Faculty, not politicians, ultimately must decide what textbooks are selected and how those materials are taught"'. (Jaschek). In this situation, leaving it up to teachers did seem like the correct course of action. The message sent out by South Carolina's House of Representatives was tyrannical and oppressive. By relying on teachers' expertise in this situation, the College of Charleston is conveying a crucial message about their educational values and their trust of teachers' judgements. They are also dictating that they will not allow the House to oppress them by dictating the kinds of novels that are taught in their institution.

Theater Professor Domenick Scudera discusses his experience teaching the novel to college freshman at Ursinus college in Pennsylvania in his essay "Teaching 'Fun Home." "He teaches the novel in a course titled Common Intellectual Experience (CIE). Scudera relates how class discussions on the novel have been educative and productive, and he asserts that students can easily relate to Bechdel. He claims that what makes Bechdel's experience relatable is how she "forges her identity, diverges from her parents, and makes her mark in the world. Our 18 year-old students are grappling with similar 
issues." (Scudera) Scudera demonstrates that he is attuned to the kinds of issues that his freshman students are experiencing. He is also suggesting that it is crucial for teenage students to identify with characters and themes in novels. Zellman and Maddow, the two honors students from chapter two, made the same point in their article when they argued in favor of having Catcher included in their high school reading list. Interestingly, the character of Alison struggles with her own identity in Fun Home just like Salinger's Holden, albeit through different circumstances. Nonetheless, Maddow's and Zellman's personal testimony demonstrates that teenage readers want to read novels that they can identify with. Scudera's interest in connecting the reading material to his students' personal lives also makes him a trustworthy educator. In this case, teachers' expertise can be relied upon if they are making informed decisions that align with their students' interests.

Furthermore, the authority of teachers should be relied upon in the service of all students, which includes those who oppose reading Bechdel's novel. Scudera mentions that he has asked students in his class if they find Bechdel's erotic scenes offensive, to which he claims that no one has. Based on Grasso's strong reaction, it is difficult to believe that there are no students at all in his class that do not find Bechdel's graphics offensive. Educators should encourage students to be sincere about why they find a text disturbing or offensive. Those students who find Bechdel's visual rhetoric pornographic should be encouraged to provide sound arguments as to why they interpret her work in this way. Teachers who want to teach Bechdel's memoir to students should be able to justify their decision to the school board, parents, and students who may be against the novel. However, those teachers also need to consider opposing views. In his essay, 
Scudera asserts that he tells students who oppose the novel to reconsider, but it is equally important for teachers to remember to be open to divergent perspectives. To handle the controversies surrounding Bechdel's novel, it is crucial for teachers to invite dissenting views and to provide all students a safe environment for debate. In the case of Huckleberry Finn, minority readers asserted that Twain's novel was "racist" to which white liberals responded by asserting that it was a "classic". Readers who object to Bechdel's novel call it "pornographic" while readers in favor say it will provide readers with a new point of view on the world. Teachers should have students define what constitutes as "pornographic," and discuss why they feel that the panel featuring sexual intercourse between Alison and her college girlfriend is pornographic.

It is important for teachers and students to consider what characteristics of Bechdel's graphic memoir illustrate its merits as a work of literature. In the case of Catcher, Mouat had discussed how Reverend Duane F. Sweet commented that Salinger's book lacked the character of other "great works." Banned books usually get deprecated by opponents, which is why it is necessary for advocates to illustrate their educational value. Advocates of Bechdel's work should specify what aspects of her book make it educative and worth including on the required reading list. Referring to specific passages and explaining what can be gained intellectually from reading Bechdel's book would be a way of channeling the discussion. Considering Grasso's comments about how he would engage with the book if it were devoid of sexual images, the topic of representation across different media should also be addressed. Opponents of Bechdel's memoir should discuss whether the book has literary merit if the sexual panel is excluded. There should also be a discussion whereby both advocates and opponents consider why Bechdel chose 
to include these sexual scenes in her book, and whether it complements or detracts from her themes. The discourse I am describing here would be challenging, which is why teachers will need to commit to facilitating these interactions and exchanges of ideas.

Teachers should use their authoritative role to facilitative a productive discussion of Bechdel's work. Prior to the beginning of the semester, teachers should reserve a venue where dissenters and students in favor of Bechdel's memoir can engage in a dialogue over its place in the required reading list. Acting as facilitative moderators, teachers should promote a sophisticated and intellectual exchange of ideas. Rather than relying on teachers' expertise to silence minority readers like in the case of Huckleberry Finn, teachers' expertise should play an integral role in allowing both sides to verbalize their perspectives. Teachers should moderate discussions between students who advocate reading Bechdel's novel and those who object. Given that conservative students are in the minority over Bechdel's memoir, they should be encouraged to explain how their religious beliefs are a crucial part of their identities and inform their interpretation of the book. Teachers should encourage liberal students to listen actively in order to understand why conservative students object to reading the novel. Similarly, liberal students should explain their stance on Bechdel's memoir and elaborate on how her novel opens readers to "new perspectives" rather than simply assuming that that is the case.

Involving students in the dialogue also could help to mitigate the controversy. Students should be a part of the larger conversation with politicians, parents, administrators, and faculty to explain why they believe Bechdel's memoir should or should not be on the required reading list. Politicians should be allowed to voice their opinions, but not in such a bigoted and hostile demeanor as Senator Garry Smith did--and 
threats of punitive actions, such as the withholding of funds, should be off the table entirely. In order for students to engage in a productive discussion, it is necessary to practice acceptance of different ideas in the decision-making process and to abstain from using bigoted and aggressive language. Furthermore, it is necessary for student participants to also be willing to change their current beliefs. Bechdel's memoir offers an opportunity for both liberal and conservative students to employ rhetoric ethically, vocalizing their perspectives in a deferential and sincere manner. Teachers again play a critical role in modeling this behavior for students by being open to changing their own perspectives. They should underscore the importance of being open to the different belief systems of others because those beliefs constitute an integral part of their identities. Teachers should also present this discourse as an exploration of divergent positions where, in the process, they may adopt those beliefs they originally disagreed with.

Disagreements over books are inevitable because readers read and interpret books differently. The controversies that emerge from these disagreements can be defused when parties ranging from administrators to students are involved in the decision-making process. However, because of their expertise, teachers should be responsible for moderating the discourse over these banned books. They are responsible for ensuring that the voices of their students are heard. If students are in favor of an assigned reading that is being threatened with censorship, teachers need to defend students' rights to read those literary works. On the other hand, it is just as essential for teachers to be open to dissenting students' perspectives and to ensure that they are not silenced. Applying these strategies can result in an efficient way of making decisions about censorship that benefits all parties involved. 


\section{Works Cited}

Arac, Jonathan. Huckleberry Finn As Idol and Target: The Functions of Criticism in Our Time. The University of Wisconsin Press, 1997.

Bart, Peter. "Obscenity Drive Opened on Coast.” New York Times (1923-Current File) 14 Aug. 1966.

http://ezproxy.fiu.edu/login?url=http://search.proquest.com.ezproxy.fiu.edu/docvi ew/117700523 ?accountid=10901 Accessed 3 Aug. 2017.

Bechdel, Alison. Fun Home: A Family Tragicomic. Houghton Mifflin Harcourt, 2006.

Birkinshaw, James. "Students Ask Why Books Were Banned at San Marino High.” Los Angeles Times (1923-Current File) 22 Jan. 1970, http://ezproxy.fiu.edu/login?url=https://search-proquestcom.ezproxy.fiu.edu/docview/156425865?accountid=10901 Accessed 5 Aug. 2017.

Boroff, David. “They Speak the Teen-agers' Language." New York Times (1923-Current File) 7 Apr. 1963. http://ezproxy.fiu.edu/login?url=https://search-proquestcom.ezproxy.fiu.edu/docview/116518400?accountid=10901 Accessed 5 Aug. 2017.

Buder, Leonard. “ 'Huck Finn'Barred as Textbook by City." New York Times (1923Current file): 1. 12 Sept. 1957. http://ezproxy.fiu.edu/login?url=https://searchproquest-com.ezproxy.fiu.edu/docview/114163745?accountid=10901. Accessed 25 Oct. 2017.

Carkeet, David. “The Dialects in Huckleberry Finn” American Literature. 51.3. (1979): 315-332. 24 Jan. 2017. http://www.jstor.org/stable/2925388?seq=1\#page_scan_tab_contents Accessed 17 April 2016.

Costello, Donald P. "The Language of 'The Catcher in the Rye." American Speech vol. 34 no. 3 (1959): pp. 172-181. JSTOR, www.jstor.org/stable/454038. Accessed 9 June. 2016.

Edwards, Duane. "Holden Caulfield: 'Don't Ever Tell Anybody Anything.," ELH, vol. 44, no. 3, 1977, pp. 554-565. JSTOR, www.jstor.org/stable/2872573. Accessed 26 Oct. 2017.

"Excerpt of Speech from My Film James Baldwin Anthology" uploaded by Claireburch, 19 Dec. 2007, https://www.youtube.com/watch?v=N7Of0Abi10A 
Fayer, Steve, and Hampton, Henry. Voices of Freedom: An Oral History of the Civil Rights Movement from the 1950s through the 1980s. Bantam Books, 1990.

Felski, Rita. The Limits of Critique. The University of Chicago Press, 2015.

Fisher Fishkin, Shelley. Was Huck Black? Mark Twain and African American Voices. Oxford University Press, 1993.

Goldstein, Phillip, and James L. Machor. New Directions in American Reception. Oxford University Press, 2008.

Grasso, Brian. 'I'm a Duke Freshman.Here's why I refused to Read Fun Home”. Washington Post. 25 Aug. 2015. https://www.washingtonpost.com/posteverything/wp/2015/08/25/im-a-dukefreshman-heres-why-i-refused-to-read-fun-home/?utm_term=.2578cc5410f4 Accessed 14 Sept. 2017.

“Huckleberry Finn”. Wall Street Journal (1923 - Current File) 16 Sept. 1957. http://ezproxy.fiu.edu/login?url=http://search.proquest.com.ezproxy.fiu.edu/docvi ew/132325596?accountid=10901 Accessed 25 July. 2017.

Jaschik, Scott. "S.C. House Keeps Financial Penalty for Gay-Themed Book”. Inside Higher Ed. 11 Mar. 2014. https://www.insidehighered.com/quicktakes/2014/03/11/sc-house-keeps-financialpenalty-gay-themed-book. Accessed 3 Sept. 2017.

Jauss, Hans Robert. Toward an Aesthetic of Reception. University of Minnesota Press, 1982.

Lee, Paula Young. 'Students Protesting Bechdel's 'Fun Home': How Clinging to 'Christian Moral Beliefs' Can End an Education Before it Even Begins” 25 Aug. 2015. https://www.salon.com/2015/08/25/students_protesting_alison_bechdels_fun_ho me_how_clinging_to_christian_moral_beliefs_can_end_an_education_before_it_ even_begins/.Accessed 14 Sept. 2017.

Lin, P. "Censorship.” Chicago Tribune (1963-Current File). 11 Oct. 1967. http://ezproxy.fiu.edu/login?url=https://search-proquestcom.ezproxy.fiu.edu/docview/169963243 ?accountid=10901. Accessed 3 Aug. 2017.

Manuel, T. Z. “Yesterday’s History.” Chicago Daily Tribune (1923-1963) 29 Sept. 1957. http://ezproxy.fiu.edu/login?url=http://search.proquest.com.ezproxy.fiu.edu/docvi ew/180183482? accountid=10901 Accessed 25 July 2016. 
Mouat, Lucia. "Guns Bombard Student Readings." The Christian Science Monitor (1908Current file): 19. Nov 17 1965. http://ezproxy.fiu.edu/login?url=https://searchproquest-com.ezproxy.fiu.edu/docview/510804126?accountid=10901Accessed 25 Oct. 2017.

“Negro Students Protest Reading 'Huckleberry Finn'."New York Times (1923-Current File), 7 Dec. 1966 http://ezproxy.fiu.edu/login?url=http://search.proquest.com.ezproxy.fiu.edu/docvi ew/117278837? accountid=10901 Accessed 25 July. 2016.

Norton, H. K. "Letters to the Times" New York Times (1923-Current File), 14 Sept. 1957 http://ezproxy.fiu.edu/login?url=http://search.proquest.com.ezproxy.fiu.edu/docvi ew/114158053? accountid=10901 Accessed 22 April. 2017.

Pack, Louise, H. “The reader writes." The Christian Science Monitor (1908-Current File), 5 Oct. 1957.

from:http://ezproxy.fiu.edu/login?url=http://search.proquest.com.ezproxy.fiu.edu/ docview/509639984? accountid=10901. Accessed 24 April. 2017.

"Report From the Nation." New York Times (1923-Current file), pp. 180, ProQuest Historical Newspapers: The New York Times, 3 June. 1962.

http://ezproxy.fiu.edu/login?url=http://search.proquest.com.ezproxy.fiu.edu/docvi ew/115690496?accountid=10901. Accessed 24 April. 2017.

"Salinger Book to Remain on Reading List”. Los Angeles Times (1923-Current File), 27 Feb.1964. http://ezproxy.fiu.edu/login?url=https://search-proquestcom.ezproxy.fiu.edu/docview/168487564?accountid=10901 Accessed 3 Aug. 2017.

Salinger, J.D. The Catcher in the Rye. Little Brown and Company, 1951.

"Salinger Novel Banned." The Christian Science Monitor (1908-Current File), 20 July 1970. http://ezproxy.fiu.edu/login?url=https://search-proquestcom.ezproxy.fiu.edu/docview/511212576? accountid=10901 Accessed 3 Aug. 2017.

“Salinger Book Stirs Controversy: Two 'Lame Ducks' on Barstow School Board Oppose Use”. Los Angeles Times (1923-Current File), 25 Apr. 1963. http://ezproxy.fiu.edu/login?url=http://search.proquest.com.ezproxy.fiu.edu/docvi ew/168311882?accountid=10901 Accessed 3 Aug. 2017. 
“School Ouster of Huck Finn Draws Fire." Chicago Daily Tribune (1923-1963) 14 Sept. 1957. http://ezproxy.fiu.edu/login?url=http://search.proquest.com.ezproxy.fiu.edu /docview/180198298? accountid=10901 Accessed 25 July. 2016.

Scudera, Domenick. "Teaching 'Fun Home”". Inside Higher Ed., 24 Aug. 2015. https://www.insidehighered.com/views/2015/08/28/essay-experience-teachingfun-home-and-why-graphic-novel-ideal-college-students Accessed 14 Sept. 2017.

Shires, Preston, Hippies of the Religious Right. Baylor University Press, 2007.

"School Board Head is Ignored Upstate on Banning Books." New York Times (1923Current File), 28 Mar. 1965. http://ezproxy.fiu.edu/login?url=https://searchproquest-com.ezproxy.fiu.edu/docview/116810608?accountid=10901 Accessed 3 Aug. 2017.

"Ban on Authors Is Urged Upstate. New York Times (1923-Current File) 7 Mar. 1965. http://ezproxy.fiu.edu/login?url=https://search-proquestcom.ezproxy.fiu.edu/docview/116797876?accountid=10901 Accessed 3 Aug. 2017.

Steinle, Pamela Hunt. In Cold Fear: 'The Catcher in the Rye' Censorship Controversies and Postwar American Character. Ohio State University Press, 2000.

"This the Negro Owes Himself." (1957, Sep 14). The Christian Science Monitor (1908Current File) 14 Sept. 1957.

from: http://ezproxy.fiu.edu/login?url=http://search.proquest.com.ezproxy.fiu.edu/ doc view/509694236? accountid=10901 26 July. 2016.

Turpin, Dick. "Uninhibited Book Stirs School Board Turmoil." Los Angeles Times (1923Current File): 1. 24 Apr.1964. http://ezproxy.fiu.edu/login?url=https://search-proquestcom.ezproxy.fiu.edu/docview/168542626?accountid=10901 Accessed 26 Oct. 2017.

Twain, Mark. The Adventures of Huckleberry Finn. Barnes and Noble Classics, 2003.

Zellman, S., \& Maddow, E. "Literary Controversy" Los Angeles Times (1923-Current File) 16 May. 1964. http://ezproxy.fiu.edu/login?url=http://search.proquest.com.ezproxy.fiu.edu/docvi ew/168550040?accountid=10901 Accessed 4 Aug. 2017. 